\title{
SYSTEMIC RACISM, POLICE BRUTALITY OF BLACK PEOPLE, AND THE USE OF VIOLENCE IN QUELLING PEACEFUL PROTESTS IN AMERICA
}

\author{
WILLIAMS C. IHEME* \\ "Our lives begin to end the day we become silent about things that matter." \\ —Martin Luther King Jr
}

\begin{abstract}
The Trump Administration and its mantra to 'Make America Great Again' has been calibrated with racism and severe oppression against Black people in America who still bear the deep marks of slavery. After the official abolition of slavery in the second half of the nineteenth century, the initial inability of Black people to own land, coupled with the various Jim Crow laws rendered the acquired freedom nearly insignificant in the face of poverty and hopelessness. Although the age-long struggles for civil rights and equal treatments have caused the acquisition of more black-letter rights, the systemic racism that still perverts the American justice system has largely disabled these rights: the result is that Black people continue to exist at the periphery of American economy and politics. Using a functional approach and other types of approach to legal and sociological reasoning, this article examines the supportive roles of Corporate America, Mainstream Media, and White Supremacists in winnowing the systemic oppression that manifests largely through police brutality. The article argues that some of the sustainable solutions against these injustices must be tackled from the roots and not through window-dressing legislation, which often harbor the narrow interests of Corporate America.
\end{abstract}

Keywords: Black people, racism, oppression, violence, police brutality, prison, bail, mass incarceration, protests.

Summary: 1. InTRODUCTION: SLAVE TRADE AS THE ENTRY POINT OF SYSTEMIC RACISM. 1.1. The central claims. 1.2. The primary aim of the research. 1.3. The research questions, methodology, and the preliminary treatment of issues. 2. THE METAPHORS UNDERLINING BLACK BODIES. 2.1. The metaphor of oppression: police brutality of black people and the silent endorsement by white supremacists in america. 2.2. Support from fellow police officers and other police-connected departments. 2.3. Support from the mainstream media. 2.4. Support from white supremacists. 2.5. A few illustrative cases of police brutality against black people in america between 1991 - 2020. 2.5.1. Rodney king (1991). 2.5.2. Amadou diallo (1999). 2.5.3. Sean bell (2006). 2.5.4. Oscar grant (2009). 2.5.5. Eric garner (2014). 2.5.6. Michael brown (2014). 2.5.7. Antwon rose (2018). 2.5.8. George floyd (2020). 3. THE METAPHOR OF HATE: PRIVATE PRISONS, MONEY BAIL, AND PROFITEERING MASS INCARCERATION OF BLACK BODIES. 3.1. Reexamining the thirteenth amendment from a functional approach - the slave plantations reincarnated as the american prisons. 3.2. Do american police officials and judges benefit from the mass incarceration of black people in america? 4. THE METAPHOR OF VIOLENCE. 4.1. America's

\footnotetext{
* LLB, LLM, SJD., Associate Professor of Law, O.P Jindal Global University, India (wciheme@jgu.edu.in; williamsiheme@gmail.com).

I am grateful to Mr. Benjamin Iheme, Sir Oliver Iheme, Mr. Gregory Iheme, Ms. Jacinta Nwachukwu, and Lady Loveline Iheme: they provided me with useful materials and personal experiences, which benefitted this research. I am also grateful to the three anonymous reviewers for their constructive and valuable feedback. I however take sole responsibility for any errors in the paper.
} 
strong economy was partially built upon violence and loots. 4.2. The lack of majoritarian criticisms of america's violence and loots. 5. CONCLUSION: THE NEED FOR MORE PROTESTS?

\section{Introduction: Slave Trade as the Entry Point of Systemic Racism}

The alleged discovery of America by Christopher Columbus and friends in $1492,{ }^{1}$ the use of refined sugar in processing food, ${ }^{2}$ and the use of wool in manufacturing cloths, ${ }^{3}$ signaled a bad omen for the African people. The vast expanse of land waiting to be cultivated with sugarcane and cotton in America motivated the search for very cheap labor. ${ }^{4}$ With the aid of navigation compasses, the scramble for resources to finance early European wars and lifestyles led Europeans to arrive the shores of Africa in the $15^{\text {th }}$ century. ${ }^{5}$

Africans were torn off from the bosoms of their families and looted off to America to work in the slave owners' plantations under highly gruesome conditions. They worked without pay nor sufficient rest until many of them died of exhaustion. ${ }^{6}$ The violent loot of human resources to build American wealth went on for 400 years, and every counter resistance by Africans was crushed and subdued with arms and ammunitions. ${ }^{7}$ Although the western (mainstream narrative) designated the violent loots as 'trade' just to whittle the abhorrence as well as give the untrue impression that the reasonable consent of African people was obtained, and the various items like liquor, mirror, comb, etc., were the contractual consideration that validated the sale of black bodies, it is difficult to believe that African family members who loved themselves, would without any threat and violence, sell off their children to foreigners in exchange for cheap liquor. ${ }^{8}$

For 400 years, i.e., about 13 - 16 generations, Black people were brutalized in the slave owners' farms, were raped, murdered, and generally treated as chattel. They lived in fear for 400 years and endured all manner of oppressive violence, lived under

\footnotetext{
${ }^{1}$ SAMUEL MORISON, The Great Explorers: The European Discovery of America (Oxford University Press, 1986), pp. $351-365$.

2 KHALIL MUHAMMAD, 'The Sugar that saturates the American Diet has a Barbaric History as the 'white gold' that fueled Slavery' New York Times (14 August 2019) <https://www.nytimes.com/ interactive/2019/08/14/magazine/sugar-slave-trade-slavery.html> accessed 6 June 2020.

3 JOSEPH INIKORI, 'Slavery and the Revolution in Cotton Textile Production in England' (1989) 13(4) Social Science History, 343-379, 344.

${ }^{4}$ ibid 360.

${ }^{5}$ Free the Slaves $<$ https://www.freetheslaves.net/about-slavery/slavery-in-history/> accessed 1 June 2020.

${ }^{6}$ US HISTORY: PRE COLUMBIAN TO THE NEW MILLENNIUM, Slave Life and Slave Code $<\mathrm{https} / /$ www.ushistory.org/us/27b.asp> accessed 6 June 2020.

7 VICTOR KAPPELER, 'A Brief History of Slavery and the Origins of American Policing' Eastern Kentucky University (7 January 2014) <https://plsonline.eku.edu/insidelook/brief-history-slavery-andorigins-american-policing > accessed 6 June 2020.

${ }^{8}$ STANLEY ALPERN, 'What Africans Got for Their Slaves: A Master List of European Trade Goods' (1995) 22, History in Africa, 5-43, 6.
} 
extremely poor conditions, were not allowed to be educated, and generally disgusted the slave owners. ${ }^{9}$

Britain during this era, was also at the forefront of Slave Trade, with its Royal African Company dominating in the Trade due to Britain's enormous naval and maritime power. ${ }^{10}$ However, after the American Revolution, and the War of 1812, Britain's relationship with the United States of America (hereafter, "America") worsened and the former started to invest more efforts toward curtailing America's rising power and influence, which was reasonably attributable to the use of slave labor in cultivating its vast land resources. ${ }^{11}$ In addition, the Industrial Revolution in the eighteenth century which witnessed the productions of goods and services with machines significantly lowered the demand for slave labor: there was no much economic incentive to continue to charter slaves in large numbers and maintain them when machines could do most of the tasks better and more efficiently. In the author's opinion, these were strong external or remote factors that led to the abolition of the Slave Trade.

In America, the principal internal factor that led to the abolition of Slave Trade was rooted more in the divergent economic interests between the North and South; ${ }^{12}$ the Trade favored the southern merchants residing closer to the Atlantic Ocean where slave ships docked. The southerners also had richer land resources and cash crop plantations that required cheap labor; ${ }^{13}$ the abolition squabbles, in the author's opinion, were therefore not truly about the genuine feelings of remorse to free the enslaved people and treat them as human beings with equal rights and dignity: it was about economic interests. ${ }^{14}$

After slavery was abolished in America in 1863, the culture of oppression against the Black people that took 400 years to crystallize could not have vanished overnight. Functionally, the experiences of Black people in the post-abolition era were largely similar to the pre-era, since the same people that oppressed them for four centuries were still in power and exclusively occupied influential economic and political positions across the country. ${ }^{15}$ The denial of the right to own farmlands, ${ }^{16}$ coupled with the denial of education ${ }^{17}$ in the 400 years of slavery, made the newly acquired freedom insignificant since they

\footnotetext{
${ }^{9}$ cf US History (n 6).

${ }^{10}$ DAVID OLUSOGA, 'The History of British Slave Ownership has been Buried: Now Its Scale can be revealed' The Guardian (London, 12 July 2015) < https://www.theguardian.com/world/2015/jul/12/britishhistory-slavery-buried-scale-revealed $>$ accessed 6 June 2020.

${ }^{11}$ FREDERICK DOUGLASS, 'British Influence on the Abolition Movement in America' An Address Delivered in Paisley (Scotland, 17 April 1846) < https://glc.yale.edu/british-influence-abolition-movementamerica $>$ accessed 6 June 2020.

12 JENNIFER WEBER \& WARREN HASSLER, 'The American Civil War' Encyclopedia Britannica

$<$ https://www.britannica.com/event/American-Civil-War/The-war-in-1862> accessed 2 June 2020.

13 ibid.

14 ibid.

${ }^{15}$ cf US History (n 6).

${ }^{16}$ VAN NEWKIRK, 'The Great Land Robbery' The Atlantic (29 September 2019) <https://www.theatlantic. com/magazine/archive/2019/09/this-land-was-our-land/594742/> accessed 4 June 2020.

${ }^{17}$ cf US History (n 6).
} 
could not cultivate food, and did not have enough money or meaningful skills to sell, in order to purchase food and rent from those who had the exclusive right to own land and other factors of production. This functionally returned the formerly enslaved people to positions of involuntary servitude, to continue to serve their former slave masters in order to fend for themselves. As Martin Luther King Jnr put it, '[B]lack people were required to pull themselves by their own bootstraps. ${ }^{\text {'18 }}$

Between the Thirteenth Amendment in 1865 (abolition of slavery), Fourteenth Amendment in 1868 (grant of citizenship to the former slaves and 'equal protection of the law'), Fifteenth Amendment in 1870 (the right to vote accorded to the Black people) on the one hand, and the 1964 Civil Rights Act which crystallized nearly two decades of agitations for true equality and protection of the law, on the other hand, the Black people endured a further 100 years of racial segregation, oppression, poverty and inequality in the country they built with their sweat and blood, even though their rights to be protected from these kinds of oppression were already inscribed in the black-letter law. ${ }^{19}$ These types of oppression, chiseled more deeply into the justice system continue to manifest loudly even till today, mainly through the law enforcement agents. Based on observations, the paper has chosen a number of metaphors to map and discuss the painful black experience in America: these metaphors have arguably become synonymous with being black in America.

\subsection{The central claims}

The paper makes a number of claims. First, it claims that the deeply encrusted culture of hate and oppression against the Black people in America is underscored in police brutality. ${ }^{20}$ The American police are the avenue through which the negative machinations and wishes against Black people by the white supremacists find expression and enforcement. Secondly, it claims that the denial of facts and defense of killing cops whenever a black person is murdered are chiseled typically in the rebuttal that "[i]t is just the act of a few bad cops who do not represent the police force." ${ }^{21}$ The paper argues that this defense is rooted in insincerity and bad faith, and is the byproduct of 'white supremacy'22 in America. In this paper, the author uses the terms: 'white supremacists', 'white Americans', and 'white people' interchangeably. Evidently, the factual accusations in this paper do not imagine white people as a race, whether those living in America or elsewhere who support the equality of all races.

\footnotetext{
${ }^{18}$ MARTIN LUTHER KING JNR, 'The Other America' Gross Pointe Historical America (14 March 1968) $<$ https://www.gphistorical.org/mlk/mlkspeech/> accessed 3 June 2020.

19 THE LIBRARY OF CONGRESS, 'The Civil Rights Act of 1964: A Long Struggle for Freedom' The Segregation Era (1900-1939) <https://www.loc.gov/exhibits/civil-rights-act/segregation-era.html> accessed 5 June 2020.

${ }^{20}$ NPR, 'A Decade of Watching Black People Die' Code Switch (31 May 2020) < https://www.npr. org/2020/05/29/865261916/a-decade-of-watching-black-people-die> accessed 6 June 2020.

${ }^{21}$ SEAM ILLING, 'Why the Police Problem Isn't about a few Bad Apples' Vox (6 June 2020) <https://www.vox. com/identities/2020/6/2/21276799/george-floyd-protest-criminal-justice-paul-butler> accessed June 72020.

${ }^{22}$ AVA KOFMAN, ET AL, 'White Supremacy Gateway to the American Mind' The Atlantic (7 April 2020) $<$ https://www.theatlantic.com/technology/archive/2020/04/white-supremacys-gateway-to-the-american$\operatorname{mind} / 609595 />$ accessed 7 June 2020.
} 
Third, it further claims that the recent (2020) incidents of police brutality against Black people which sparked outrage on the Internet from around the globe pail into insignificance in comparison to what they had suffered in the past without much global attention due to the absence of the Internet. In other words, the culture of hate against Black people in America was not recently developed, instead the heightened use of smart phones in the $21^{\text {st }}$ century has helped to create more awareness, consciousness, and exposure of the cruelty and brutality by the American police for centuries. ${ }^{23}$ This claim is embellished by the video records showing the level of mastery with which the brutality is usually carried out, the perfect use of deadly tactics in tackling down, handcuffing, and skillfully choking Black people to death even in broad daylight, amidst a global spectacle. ${ }^{24}$

In the past when there was little opportunity for the world to see these wrongful arrests and extra judicial killings, the police had managed to develop a set of excuses over the centuries, which are typically propagated by the mainstream media to show that Black people were at the relevant time deserving of their death by allegedly resisting arrest, fleeing from the scene of crime, attempting to grab a police officer's weapon, or were already ill with diseases, as if to suggest that they would have died anyways, etc. ${ }^{25}$ Other times, when it is not convenient to draw from the established excuses, the deceased (the black person)'s past criminal record, if any, their health data, even though unrelated, are dug out and declared as contributory factors to the death. ${ }^{26}$ In the case of George Floyd, the mainstream media reported post mortem that he tested positive for Covid-19. ${ }^{27}$ In many instances, the policemen that carried out the murder were never charged at all, or were charged with the least possible offence with significantly reduced sentences, ${ }^{28}$ and sometimes released under parole before the end of their imprisonment term. ${ }^{29}$ This level of injustices continues to create

\footnotetext{
${ }^{23}$ NICOL LEE, 'Where would Racial Progress in Policing be without Camera Phones' Brookings (5 June 2020) < https://www.brookings.edu/blog/fixgov/2020/06/05/where-would-racial-progress-in-policing-bewithout-camera-phones/> accessed 7 June 2020.

${ }^{24}$ BBC, 'George Floyd: 'Pandemic of racism' led to His Death, Memorial Told' BBC News (5 June 2020) $<$ https://www.bbc.com/news/world-us-canada-52928304> accessed 6 June 2020.

${ }^{25}$ ALFRED COTTON, 'Do Black Lives Matter in American Mainstream News Media? Two Case Studies of Police-involved Shootings of Black Men explaining a racist Media Environment' (DPhil thesis, 2016) $<$ https://uknowledge.uky.edu/comm etds/52> accessed 6 June 2020.

${ }^{26}$ ADAM JOHNSON, 'How the Media Smears Black Victims' Los Angeles Times (30 March 2017) $<$ https://www.latimes.com/opinion/op-ed/la-oe-johnson-black-victim-20170330-story.html $>$ accessed 6 June 2020.

${ }^{27}$ ASSOCIATED PRESS, ‘Autopsy Report Shows Floyd Tested Positive for Coronavirus' US News (4 June $2020)<$ https:/www.usnews.com/news/us/articles/2020-06-03/autopsy-report-shows-floyd-had-tested-posi tive-for-covid-19> accessed 6 June 2020.

${ }^{28}$ MADISON PARK, 'Police Shootings: Trials, Convictions are rare for Officers' CNN (3 October 2018) $<$ https://edition.cnn.com/2017/05/18/us/police-involved-shooting-cases/index.html $>$ accessed 7 June 2020.

${ }^{29}$ DAILY MAIL REPORTER, 'Former Police Officer who killed Unarmed Black Train Passenger is Released from Jail After Serving Just 11 Months’ Mail Online (13 June 2011) <https://www.dailymail. co.uk/news/article-2003074/Johannes-Mehserle-killed-Oscar-Gran-released-jail-serving-11-months.html> accessed 5 June 2020.
} 
unbearable pain to the black community as well as incalculable fear and tension about their existence. ${ }^{30}$

The fourth claim of this paper is that the white supremacists who designate black protesters as violent thugs and looters in breach the social contract, are worse in character and are not sincerely opposed to the acts of theft and violence: in any case, the wealth of America was built largely by looting resources with violence and thuggery from around the globe. This claim observes that often times when the police kill Black people unjustly, and no real justice takes place to address the wrong due to the systemic racism and injustice, not many white Americans cry out as patriots and protest for such injustice done to their fellow citizens. In American history, black protests are an avenue through which the unheard and marginalized voices seek to be heard, an avenue to show their level of disapproval of the system's unjust treatments against them, a passionate appeal for the Government and civil society to come to their aid, and a call for the stopping of the Government's sponsored loot of their rights and bodies. ${ }^{31}$ As Martin Luther King alluded, perhaps, when the right to protest was guaranteed under the First Amendment in 1789, many white supremacists did not envisage that 74 years afterward, it would become the strongest weapon against the systemic oppression of Black people. ${ }^{32}$

America and its white supremacists have looted resources from around the globe in sustaining themselves, starting from the Slave Trade, destabilization of families and the incessant bombing of the Middle Eastern and Asian countries for their crude oil, ${ }^{33}$ sponsorship of cooperative dictators in Africa including assisting them to bank embezzled funds, ${ }^{34}$ all for the sake of their oil resources. ${ }^{35}$ This ill-acquired wealth is brought home and largely owned by white Americans who command more than $80 \%$ of the total American wealth, ${ }^{36}$ which enables them to highly influence the country's politics, law, justice system,

${ }^{30}$ MICHAEL FLETCHER, 'For Black Motorists, a Never-Ending Fear of Being Stopped' National Geographic Magazine/ the Race Issue <https://www.nationalgeographic.com/magazine/2018/04/the-stoprace-police-traffic/> accessed 7 June 2020.

${ }^{31}$ TIM DECHRISTOPHER, 'The Value of Protest' Moyers on Democracy (23 July 2015) <https://billmoyers. com/2015/07/23/the-value-of-protest/> accessed 6 June 2020.

${ }^{32}$ MARTIN LUTHER KING JNR, 'I Have a Dream' The March on Washington (1963) <https://www. archives.gov/files/press/exhibits/dream-speech.pdf> accessed 7 June 2020.

${ }^{33}$ ANTHONY CORDESMAN, 'The One True U.S. Strategic Interest in the Middle East: Energy' Middle East Policy Council (Spring 2001) <https://mepc.org/journal/one-true-us-strategic-interest-middle-eastenergy $>$ accessed 7 June 2020.

${ }^{34}$ Most of Abacha's embezzled funds were banked in the United States for over two decades. LIBBY GEORGE, 'U.S., Jersey sign \$300 million Abacha Loot Reparation Deal with Nigeria' Reuters (4 February 2020) <https:/www.reuters.com/article/us-usa-nigeria/u-s-jersey-sign-300-million-abacha-lootrepatriation-deal-with-nigeria-idUSKBN1ZY1W0> accessed 6 June 2020.

${ }^{35}$ As Dick Cheney aptly put it, 'the good Lord didn't see fit to put oil and gas only where there are democratically-elected regimes friendly to the United States. Occasionally we have to operate in places where, all things considered, one would not normally choose to go. But, we go where the business is." BRIAN WHITAKER, 'Fueling the Status Quo' The Guardian (5 April 2004) <https://www.theguardian. com/world/2004/apr/05/worlddispatch.oil\#maincontent>accessed 7 June 2020.

${ }^{36}$ CHUCK COLLINS, ET AL, 'The Racial Wide Divide Report' Institute for Policy Studies (2019) 11 $<$ https://inequality.org/wp-content/uploads/2019/01/IPS_RWD-Report_FINAL-1.15.19.pdf> accessed 7 June 2020 . 
etc., to their advantage. The ultimate beneficiaries of these loots do not protest against the looting and violent acts of their Government on innocent people abroad. However, when Black people protest on the streets against racism, and a white supremacist group 'hijacks' the protests so as to obstruct or change the narrative, ${ }^{37}$ Black people as a result, are labelled as barbaric thugs and terrorists, criticized for breaching their social contract and consequently lectured on how best to behave and express their anger against the system that oppresses them. ${ }^{38}$

The fifth and last claim is that the anger and disapproval that are felt by observers of black protests whereby properties are damaged, indeed pale into insignificance to the pain and suffering that is systemically unleashed by the American Government against Black people who are engulfed daily by the fear of indiscriminate arrests and the accompanying inability to bail themselves from detention due to high money bail. ${ }^{39}$ All this makes it difficult for Black people to maintain steady employment or be hired for meaningful positions especially if they had unjustly sustained a high number of criminal records ${ }^{40}$ Similarly, due to frequent racial profiling and arrests, they stand a higher chance of being murdered by the police, higher chance of going to prison and serving a highly disproportional prison term, ${ }^{41}$ growing up poor and without parents because they are in prison, ${ }^{42}$ regularly cheated by their banks for mortgage and consumer loans via higher interest rates, ${ }^{43}$ etc. In the year 2020, it is submitted that these tales are unbefitting of a country that claims to be a great defender of rule of law and human rights.

\subsection{The primary aim of the research}

The primary aim of this research is to convincingly show that irrespective of it being 2020, and the American Congress churning out numerous laws on human rights

\footnotetext{
${ }^{37}$ SEEMA SIROHI, 'US Protests: Why Black Activists Need Real Allies, Not 'Hijackers” The Quint (3 June 2020) <https://www.thequint.com/voices/opinion/george-floyd-killing-police-brutality-america-protestsblack-lives-matter-vandalism-versus-peaceful-protest $>$ accessed 6 June 2020.

${ }^{38}$ CALVINJOHN SMILEY \& DAVID FAKUNLE, "From "brute" to "thug:" The Demonization and Criminalization of Unarmed Black Male Victims in America' (2016) 26 Journal of Human Behavior in the Social Environment, 2-3. <https://www.tandfonline.com/doi/full/10.1080/10911359.2015.1129256>; ADRIAN HORTON, 'John Oliver: When Trump uses the word Thugs, you know what it's Code for' The Guardian (1 June 2020) <https://www.theguardian.com/culture/2020/jun/01/john-oliver-when-trump-usesthugs-code-racism-george-floyd-protests $>$ accessed 7 June 2020.

${ }^{39}$ BERNADETTE RABUY \& DANIEL KOPF, 'Detaining the Poor: How Money Bail perpetuates an endless Cycle of Poverty and Jail Time' Prison Policy Initiative (10 May 2016) <https://www.prisonpolicy. org/reports/incomejails.html> accessed 1 June 2020.

${ }^{40}$ ANDRE PERRY, 'You Can't Have an Equitable Economy While Ignoring Police Violence' City Lab (28 March 2019) <https://www.citylab.com/perspective/2019/03/pittsburgh-police-shooting-antwon-rose-jobseconomy $/ 585841 />$ accesed 7 June 2020.

${ }^{41}$ ibid.

${ }^{42}$ LOTTIE JOINER, 'How absent Fathers are hurting African American Boys' Center for Health Journalism, University of South Carolina <https://www.centerforhealthjournalism.org/resources/lessons/lessonsreporting-how-absent-fathers-are-hurting-african-american-boys> accessed 7 June 2020.

${ }^{43}$ KHRISTOPHER BROOKS, 'Disparity in Home Lending Costs Minorities Million, Researchers Find' CBS News (15 November 2019) <https://www.cbsnews.com/news/mortgage-discrimination-black-andlatino-paying-millions-more-in-interest-study-shows/> accessed 6 June 2020.
} 
both for its domestic use and for export to other jurisdictions, coupled with its claim of being a great defender of rule of law and human rights, the Black people in America do not generally experience the effects of these American claims in their daily lives. The pure capitalist approach which has crystallized into the private ownership and management of prisons and bail bonds for profit, further complicate the matter for Black people: the owners of the bail bond and prison corporations generally see the former as fattened geese that lay golden eggs, thus, 'hunting' them down in the streets of America. ${ }^{44}$ Therefore, the law-in-books do not work effectively for Black people as much as they work for their white American counterparts. Hence, a set of bespoke, sustainable, and less orthodox solutions must be developed and implemented to help the Black people in America overcome the stranglehold of systemic racism.

\subsection{The research questions, methodology, and the preliminary treatment of issues}

I.) The first question probes whether the American police enjoy any form of support from white supremacists (individuals and corporations) in the brutality, arrest, and unfair imprisonment of Black people?

To answer this question, the author defines support to be any direct or indirect endorsement of police brutality against Black people in America. The author uses a few famous cases between 1991 and 2020 in which the police used brutal force to unjustly kill unarmed Black people, to examine how the mainstream media owned and largely controlled by white Americans reported the incidents. Applying a reasonable person's test, the author inquires whether a fair reporting which truly narrated the facts as they occurred was done, and whether the acknowledged brutality was derailed by focusing on extrinsic facts that were irrelevant to the circumstances surrounding the black victim's death, and how all this relates to the protection of the vested interests of many white Americans.

The author also examines the typical responses of white supremacists whenever a policeman brutally kills a black person in America, even in circumstances where video records show that the nature of force used was excessive and illegal. The author further examines the typical utterances with the theory of bias, social contract theory, and human rights, to show that the social contract which the Black people entered into with America is fundamentally breached on a regular basis by the latter without any adequate remedy, but is highly enforced whenever it is perceived that a black person is in breach. The author examines this question more concretely below under the theme titled the ('Metaphor of Oppression').

II.) In answering the second question, the author examines the level of enthusiasm, the perfected skills of assault against black bodies, and the inception of police brutality against the Black people which dates back to several centuries in

\footnotetext{
${ }^{44}$ JOSEPH GOLDSTEIN \& ASHLEY SOUTHALL, ' I Got Tired of Hunting Black and Hispanic People' New York Times (9 December 2019) <https://www.nytimes.com/2019/12/06/nyregion/nyc-police-subwayracial-profiling.html $>$ accessed 6 June 2020.
} 
America. The author finds a reasonable correlation between this heightened level of brutality, racial profiling, random stop and frisk, and unfair justice system on the one hand, and private ownership of prison and bail bond corporations, which are largely owned by white Americans, and for which the brutality of police and unfair court decisions are the initial steps toward accomplishing the larger aim of profiting from the mass incarceration of black bodies, on the other hand. Curiously, the author inquires whether some policemen, judges, and key official in the justice system, somehow profit from the mass incarceration either as shareholders of these bail and prison corporations or direct recipients of bribes from the controlling shareholders and managers of these corporations? $?^{45}$

Here, the author employs the Adverse Inference, ${ }^{46}$ Shareholder Primacy, and Reasonable Suspicion of Bias theories to attempt the question. Also, some notable cases of police brutality against Black people are examined below to find out how many policemen were charged for their crimes ${ }^{47}$ Similarly, even though wearing of body cameras when confronting citizens was thought to be a win-win for the American police and Black people ${ }^{48}$ nearly always, the police in cases of brutality claimed that they forgot to turn on their body cameras or that it became mysteriously defective at the relevant time. ${ }^{49}$ The author uses statistical data as well as anecdotal evidence regarding the frequency of search and arrest of Black people, degree of sentencing for crimes committed by them compared with their white counterparts who are treated with exceptional kindness: often given water to drink (Sebastian Arzadon), ${ }^{50}$ and hamburger to eat (Dylann Roof) ${ }^{51}$ during arrests for suspected murder offences. It is argued that this imbalance reveals the existence of a systemic hate that ravages the lives and hopes of Black people in America: this is examined more concretely through the lens of shareholder primacy rule, which is arguably the main motive for the existence of the profit-oriented bail and prison corporations in America. This question is discussed more critically under the theme titled the ('Metaphor of Hate').

\footnotetext{
${ }^{45}$ Ibid.

${ }^{46}$ See bodycam video released by police capturing other events in the killing of Paul O'Neal except the shooting part.

${ }^{47}$ ROB ARTHUR, ET AL, 'Shot by Cops and Forgotten' VICE News (11 December 2017) < https://news. vice.com/en_us/article/xwvv3a/shot-by-cops> accessed 7 June 2020.

${ }^{48}$ JAY STANLEY, 'Police Body-Mounted Cameras: With Right Policies in Place, A Win For All' ACLU (March 2015) <https://www.aclu.org/other/police-body-mounted-cameras-right-policies-place-winall?redirect=police-body-mounted-cameras-right-policies-place-win-all $>$ accessed 4 June 2020.

${ }^{49}$ MATHEW SEAGAL, 'If Cops Don't Turn on Their Body Cameras, Courts Should Instruct Juries to Think Twice about Their Testimony' $A C L U$ (1 December 2016) <https:/www.aclu.org/blog/criminal-law-reform/ reforming-police/if-cops-dont-turn-their-body-cameras-courts-should $>$ accessed 7 June 2020. Also see the bodycam video which the police released following their shooting of Paul O'Neal.

${ }^{50}$ NEWS CHANNEL 5, 'Suspect arrested for Lawrenceburg Double Murder' News Channel 5 (28 May $2020)<$ https://www.newschannel5.com/news/suspect-arrested-for-lawrenceburg-double-murder $>$ accessed 7 May 2020.

${ }^{51}$ ABC, 'Cops bought Burger King for Dylann Roof following his Arrest' Eyewitness News (23 June 2015) $<$ https://abc7.com/dylann-roof-south-carolina-church-shooting-emanuel-african-methodist-episcopal /801013/> accessed 6 June 2020.
} 
III.) Black people who protest on the streets of America against systemic racism and injustices are frequently labeled as violent thugs, terrorists, and looters of property in breach of the social contract. ${ }^{52}$ The author asks whether the white supremacists giving these labels are truly opposed to acts of violence, thuggery, and theft of property given that the wealth of America which they largely own, ${ }^{53}$ were acquired by the American Government from other countries using rebel fighters, ${ }^{54}$ deception, violence, thuggery, bombs ${ }^{55}$ and boots, as in Iraq,${ }^{56}$ Afghanistan, ${ }^{57}$ Libya,${ }^{58}$ Vietnam,,${ }^{59}$ etc., : yet the government does not receive any serious criticisms for their acts by majority of the white Americans who accuse these black protesters of violence? A corollary question is whether the nature of protests, for instance, the type undertaken in the aftermath of George Floyd's death, has been beneficial to Black people in achieving their just causes in America, and if so, whether the discouragements from white supremacists in this regard are ill-motivated faith?

The paper further examines the motives behind America's strong military presence and interests in Africa, Asia and Middle East. The wars it has fought, and the natural resources it has plundered from other countries beginning with the Slave Trade, and how these spoils have helped to build its economic empire without any significant outrage from white Americans against the Government's heinous crimes against humanity. The paper uses the legal concept of trust to discuss this question, and show why the looted

52 CAVIN ROBINSON, 'Social Contract Theory, African American, Slave Narratives, and the Reconstruction of Early Modern Conceptions of Political Freedom' (DPhil thesis, DePaul University 2011) <https://via.library.depaul.edu/cgi/viewcontent.cgi?referer=https://www.google. com/\&httpsredir $=1 \&$ article $=1082 \&$ context $=$ etd $>$ accessed 7 June 2020.

${ }^{53}$ cf Chuck Collins, et al, (n 36).

${ }^{54}$ JAMES RISEN, ET AL, 'U.S.-Approved Arms for Libya Rebels Fell into Jihadis' Hands' New York Times (5 December 2012) <https://www.nytimes.com/2012/12/06/world/africa/weapons-sent-to-libyan-rebelswith-us-approval-fell-into-islamist-hands.html> accessed 31 May 2020.

${ }^{55}$ NAJIM RAHIM \& ROD NORDLAND, 'A Family of 14 Dies in an Airstrike. U.S. Officials Deny They Were Civilians' The New York Times (20 July 2018) <https://www.nytimes.com/2018/07/20/world/asia/ afghanistan-us-civilian-casualties.html> accessed 2 July 2020.

${ }^{56}$ ERIC BONDS, 'Assessing the Oil Motive After the U.S. War in Iraq' (2013) 25:2 Peace Review, 291298, DOI: 10.1080/10402659.2013.785769; ANTONIA JUHASZ, 'Why the War in Iraq was fought for Big Oil' CNN (15 April 2003) <https://edition.cnn.com/2013/03/19/opinion/iraq-war-oil-juhasz/index.html> accessed 4 June 2020.

${ }^{57}$ ROD NORDLAND, ET AL, 'How the U.S. Government Misleads the Public on Afghanistan' The New York Times (8 September 2018) <https:/www.nytimes.com/interactive/2018/09/08/world/asia/usmisleads-on-afghanistan.html>; Sue Lannin, 'Afghanistan to begin first Commercial Oil Production' $A B C$ News (18 May 2013) <https://www.abc.net.au/news/2013-05-18/australia-backs-afghan27s-strugglingminers/4698082\#: :text=Afghanistan\%20has\%20untapped $\% 20$ mineral\%20and,income $\% 20$ of $\% 20$ $\% 24470 \% 20$ per\%20year.> accessed 5 June 2020.

${ }^{58}$ CHRISTOPHER DAVIDSON, 'Why was Muammar Qadhafi Really Removed?' (2017) 24(4) Middle East Policy, 91-116.

${ }^{59}$ MICHAEL KLARE, 'Twenty-first Century Energy Wars: How Oil and Gas are fueling Global Conflicts' Energy Post (15 July 2014) <https://energypost.eu/twenty-first-century-energy-wars-oil-gas-fuellingglobal-conflicts/> accessed 31 May 2020. 
resources ought to constitute America a constructive trustee. ${ }^{60}$ Also, the paper ponders a little about how the growing request for America's reconciliation and reparation of Black people for their enslavement for 400 years has been generally treated by white supremacists in America. It also assesses the level of significance of black protests given that the system they protest against is hardwired to oppress and keep them impoverished and on the periphery of American life. These questions are examined below under the theme titled the ('Metaphor of Violence').

\section{The Metaphors Underlining Black Bodies in America}

As earlier mentioned above, the justification for the choice of metaphors is rooted in the common observations, repeatedly reinforced in the American mainstream media, regarding how the 'black body' has become a symbol or almost synonymous with oppression, hate, violence, and even poverty. Since the metaphors and black bodies have nearly become synonymous owing largely to racism in America, this paper uses these familiar metaphors to analyze the issues surrounding police brutality in order to enable the reader appreciate the issues from their historical and contemporary standpoints.

\subsection{The Metaphor of Oppression: police brutality of black people and the silent endorsement by white supremacists in America}

As hinted earlier, this paper designates white people in America who support racism in any way as 'white supremacists'. According to data, Black people in America make up $13.4 \%$ of the total population, ${ }^{61}$ and have been estimated to be $2.5 \%$ more likely to be killed by the police than their white counterparts. ${ }^{62}$ California, Florida and Texas rank as top states where police officers have disproportionately killed Black people. ${ }^{63} \mathrm{In}$ Utah, the Black people are $1.06 \%$ of the total population, ${ }^{64}$ yet they constituted $10 \%$ of the police killings over a period of 7 years data, a clearly disproportionate rate of about 9.21 times more likely to be killed by the police compared to their white counterparts. ${ }^{65}$ In Minnesota where George Floyd was killed by a police officer, Black people are nearly four times more likely to be killed by the police, and comprise of $20 \%$ of those killed

\footnotetext{
${ }^{60}$ LIBY GEORGE, 'U.S., Jersey sign \$300 million Abacha Loot Reparation Deal with Nigeria' Reuters (4 February 2020)<https:/www.reuters.com/article/us-usa-nigeria/u-s-jersey-sign-300-million-abacha-lootrepatriation-deal-with-nigeria-idUSKBN1ZY1W0> accessed 6 June 2020.

${ }^{61}$ UNITED STATES CENSUS BUREAU, 'Black or African American Population in the United States' (2019) < https://www.census.gov/quickfacts/fact/table/US/IPE120218> accessed 7 June 2020.

${ }^{62}$ WESLEY LOWERY, 'More Whites killed by Police, but Blacks 2.5 Times More Likely to be Killed' Chicago Tribune (11 July 2016) <https://www.chicagotribune.com/nation-world/ct-police-shootings-race20160711-story.html> accessed 3 June 2020.

63 MOHAMMED HADDAD, 'Mapping US Police Killings of Black Americans' Aljazeera (31 May 2020) <https://www.aljazeera.com/indepth/interactive/2020/05/mapping-police-killings-blackamericans-200531105741757.html > accessed 5 June 2020.

64 ibid.

65 ibid.
} 
despite being only $5 \%$ of the total population. ${ }^{66}$ In Washington D.C, the Black people constitute about $50 \%$ of the total population, and comprised of $88 \%$ of the total police killings, which is a discrepancy of about $38 \% .{ }^{67}$ In Rhode Island, the discrepancy rate was about $44 \% .{ }^{68}$ And about "99 percent of all officers involved in all police killings had no criminal charges pressed against them." ${ }^{\prime 69}$

Of course, it is impossible for any statistical data to capture all the police killings in America. Yet, it is important to underline that in all the cases, nearly all the policemen involved were white Americans, and were not charged with any offence by the grand juries and police departments who are also largely dominated by white Americans. If in 99 $\%$ of the time, the police who killed unjustly were not charged, then it becomes a strong but tacit support for their wrongdoing. So, below, based on the author's review of the relevant events, three main forms of support that are regularly enjoyed by white American police officers who harass and kill Black people unjustly are identified and discussed.

\subsection{Support from fellow police officers and other police-connected departments}

The first is a direct support from a killer-cop's fellow police officers (prosecutors) who cover up for the former's wrongdoing by not bearing true witness and pressing criminal charges in most of the cases. ${ }^{70}$ In the author's view, they do not press charges or give factual evidence against their fellow officers, perhaps, because it protects the broader agenda of making money out of incarceration, and also as a personal hedge against being charged in the future, in the likely event they unjustly kill a black person. ${ }^{71}$ Given that in a criminal case, the prosecutor has to satisfy a higher standard of proof, i.e. proof beyond a reasonable doubt, obtaining a justifiable conviction is only possible if the prosecution counsel is truly committed in gathering sufficient evidence to achieve justice in a given case. The entire police force therefore engages seemingly in some barter trade with black bodies, giving and receiving favors amongst themselves.

Similarly, the connected departments that work to provide support to the police, e.g., provision of medical attention to victims in a crime scene, conducting lab tests or autopsy to provide a scientific guidance to investigations, have also been largely compromised. ${ }^{72}$ This compromise stems from their subservience and lack of independence, and the fact

\footnotetext{
66 ibid.

67 ibid.

68 ibid.

${ }^{69}$ ibid.

${ }^{70}$ Ibid. Also see the cases discussed in section 2.6 below. Also see Ben Crump, 'I Believe Black Americans Face a Genocide. Here's Why I Choose that Word' The Guardian (15 November 2019) <https://www.theguardian. com/commentisfree/2019/nov/15/black-americans-genocide-open-season> accessed 4 June 2020.

${ }^{71}$ MELLISA CHAN, 'A Police Officer Killed Their Mother, and Her Sons Want to Know Why He Hasn't Faced Trial' TIME (18 July 2019) <https://time.com/5628206/police-shooting-trial-knowlton-garner/> accessed 5 June 2020.

${ }^{72}$ RADLEY BALKO, 'It's Time to Abolish the Coroner' The Washington Post (12 December 2017) <https:// www.washingtonpost.com/news/the-watch/wp/2017/12/12/its-time-to-abolish-the-coroner/> accessed 7 June 2020.
} 
that they need the endorsements of the high ranking officers in the police department to generally thrive and prevent any fall from their career scaffold. ${ }^{73}$ As Coroners and Medical Examiners are usually appointed, the saying that "whoever that pays a piper dictates the tune' is apt in describing the relationship between the police and the support departments connected to them. The further challenge is that if a worker in a policeconnected department had at one point been compromised, they lose their credibility and moral right to speak out in other wrongdoings, since those who seek equity and justice would normally do so with clean hands. ${ }^{74}$ All this leads finally to the frequent manipulation of evidence to suit whatever narrative the police chiefs want the public to hear, ${ }^{75}$ and in many instances, Black people have been falsely prosecuted for murder and rape ${ }^{76}$ losing their lives and languishing in prison for decades (sometimes for 36 years) ${ }^{77}$ because the police suppressed evidence and hid it from the defense counsel; evidence that would have exonerated and resulted to their acquittal $a b$ initio. $^{78}$

The police culture of hiding or manipulating evidence to suit their narrative is so deeply encrusted, such that even though George Floyd was killed in broad daylight in the full spectacle of the world, whereby a white policeman knelt heavily at the back of his neck for about nine minutes, three minutes of which was after Mr. Floyd was no longer responsive, the autopsy report conducted by the police-connected-department purportedly showed that "arteriosclerotic and hypertensive heart disease; fentanyl intoxication; and recent methamphetamine use," had contributed to Mr. Floyd's death, ${ }^{79}$ thereby mitigating or partially excusing the evil-styled execution the world had eye-witnessed in the hands of Derek Chauvin, and the other three police officers who assisted him in the execution. This shocking attitude of the state medical examiners underlines the high level of support these killing cops receive for their wrongdoings: this raises a further critical but rhetorical question: if the medical examiners could try to manipulate evidence for a killing that was observed by the entire world as it happened, what more about other killings that were not video-recorded? This type of support given by fellow police officers and the connecteddepartments to cops that unjustly kill Black people is oppressive and incompatible with the American hymn of being a 'land of the free'.

\footnotetext{
${ }^{73}$ ibid.

74 ibid.

75 ibid.

${ }^{76}$ For a comprehensive list of wrongful convictions of Black people, see SAMUEL GROSS, ET AL, 'Race and Wrongful Convictions in the United States' National Registry of Exonerations (7 March 2017) <http:// www.law.umich.edu/special/exoneration/Documents/Race_and_Wrongful_Convictions.pdf $>$ accessed 5 June 2020.

${ }^{77}$ BBC, 'Maryland Trio Set Free After Being Wrongfully Jailed for 36 Years' BBC News (26 November $2019)<$ https://www.bbc.com/news/world-us-canada-50557396> accessed 7 June 2020.

${ }^{78}$ In the Central Park Five, the DNA found on the scene of crime did not match with the accused persons, yet, the police suppressed this finding, and relied on the involuntary confessions of the suspects to obtain convictions. BBC, 'Central Park Five: The True Story Behind When They See Us' BBC News (12 June 2019) <https://www.bbc.com/news/newsbeat-48609693> accessed 5 June 2020.

${ }^{79}$ RACHEL SANDLER, 'George Floyd Had Coronavirus, Autopsy Finds, But it wasn't a Factor in His Death' Forbes (3 June 2020) < https://www.forbes.com/sites/rachelsandler/2020/06/03/george-floyd-hadcoronavirus-autopsy-finds-but-it-wasnt-factor-in-his-death/\#3e87558c2b44> accessed 3 June 2020.
} 


\subsection{Support from the mainstream media}

The second form of support that these killing cops in America receive comes from the mainstream media which are largely owned by white Americans. ${ }^{80}$ Nearly always, as soon as a Black person is killed unjustly by the police, the mainstream media swing in to constitute themselves the jury and judge. Even where there is a dashboard camera, body camera, or a nearby circuit camera television video record of the killing event, the police and media skillfully edit out portions of the video record that might incriminate the concerned police officer(s), and then present it in a fast motion and haphazard manner to the public for just a few seconds, such that no reasonable comprehension of what happened can be achieved by the viewers. ${ }^{81}$ They also announce that the full story is not yet known since no one knows exactly what transpired prior to the video recording, between the murdered Black person and the police. To further sow a seed of doubt in the public's mind, they often speculate that they do not know for sure whether the deceased was resisting arrest or fleeing from the scene of crime.

Almost immediately, the mainstream media redirect the public's attention to an alleged bad character of the deceased Black person, ${ }^{82}$ showing mugshots of him, if any, and any past criminal records, almost to suggest that his death was deserved. ${ }^{83}$ Sometimes, the deceased's apartment is searched by the police post-mortem, just to locate or implant ${ }^{84}$ any evidence they believe will help their narrative, and the mainstream media focus on such irrelevant pieces of information as red-herring toward legitimizing the wrongful killing. Similarly, the mainstream media tacitly endorse the killing of the Black person by showing the killing cop's elegant photographs in his official uniform, perhaps taken during his graduation from the police academy, alongside a mugshot of the victim, as was in Samuel Dubose case. ${ }^{85}$ In the author's view, this is done to forcibly impress on the mind of the public that this was just a good cop trying to rid society of a very bad person. This skewed type of narrative is championed regularly by the mainstream media

\footnotetext{
${ }^{80}$ cf Adam Johnson (n 26).

${ }^{81}$ SUE DREMANN, 'Report: Police Tampered with Taser Recordings' Palo Alto Online (1 December 2008) $<$ https://www.paloaltoonline.com/news/2008/12/01/report-police-tampered-with-taser-recordings $>$; JEFF PROCTOR, 'DA: Allegations of Police Tampering with Video warrant Federal Investigation' Criminal Justice \& Public Safety (21 November 2016) <https://nmpoliticalreport.com/2016/11/21/da-allegations-ofpolice-tampering-with-video-warrant-federal-investigation/> accessed 7 June 2020. Also see the bodycam video record that was released by the police following the shooting of Paul O'Neal which reasonably indicates that it was edited to ensure against the conviction of the cops for wrongful killing.

82 cf ADAM JOHNSON (n 26).

${ }^{83}$ THE ENQUIRER, 'A Flag Photo of a Murder Suspect, a Mugshot of a Victim' Cincinnati.com (29 July $2015)<$ https:/www.cincinnati.com/story/news/2015/07/29/sam-dubose-social-media-reaction-photo/3085 8745/> accessed 6 June 2020.

${ }^{84}$ MEAGAN FLYNN, 'US Officer pulled random People over and Planted Meth inside their Cars, causing them to lose their Freedom, their Children, their Marriages' Independent (12 July 2019) <https:// www.independent.co.uk/news/world/americas/police-us-planted-evidence-meth-marijuana-cars-floridazachary-a9001961.html> accessed 6 June 2020; SUSAN CRISS, 'Protecting Bad Police undermines Law and Order' The Daily News (7 June 2020) <https://www.galvnews.com/opinion/guest_columns/article_ f6f214de-b626-566e-bc52-284922d7461c.html> accessed 7 June 2020.

${ }^{85}$ cf THE ENQUIRER (n 83), 'A Flag Photo of a Murder Suspect, a Mugshot of a Victim'.
} 
to deflect any possibility of angry protests that might endanger the property of the white Americans. ${ }^{86}$

\subsection{Support from white supremacists}

The concept of 'white privilege' ${ }^{87}$ in America is underlined by the favorable treatment white Americans exclusively receive from the police: the former know exactly how to use this privilege against Black people, as was in the Central Park Five case in 1989. The accused persons in this case were later found to be innocent in 2002, even though at the time of accusation, Donald Trump had spent $\$ 85,000$ in front cover adverts advocating for their death, stating in strong terms that he 'hated' them. ${ }^{88}$ More recently in 2020, Christian Cooper, a Black man, was lucky to escape a potential death or prison sentence while watching birds in the Central Park, where a white woman had dialed 911 and falsely cried out or reported that she 'was being threatened and harassed by an African American man', Mr. Cooper. ${ }^{89}$ The recorded video evidence to the contrary went viral on the Internet and helped to save Cooper in the circumstance, thus avoiding a repeat of the Central Park Five.

White Americans (many of whom acknowledge it) do not generally experience negative profiling that leads to incessant stopping, frisking, and arrest by the police and the possibility of having an incident escalated to the point that seemingly justifies brutality. Most times, Black people are arrested and handcuffed for no good reason other than that the victim was resisting arrest even when not under arrest, or 'disrespecting' the police. ${ }^{90}$ Also, white supremacists in America enjoy enormous benefit of the doubt from the police and are considered as 'very fine people.' For instance, when they protested on the streets with guns against Covid-19 'social distancing' policies, ${ }^{91}$ or protested with Nazi flags $^{92}$ and chanted racial slurs against people of other races, the president of the country,

\footnotetext{
${ }^{86}$ TRACY EVERBACH, ET AL, “\#IfTheyGunnedMeDown: An Analysis of Mainstream and Social Media in the Ferguson, Missouri, Shooting of Michael Brown' (2018) 12(1) Electronic News 23-41 <https:// journals.sagepub.com/doi/pdf/10.1177/1931243117697767> accessed 7 June 2020.

${ }^{87}$ CORY COLLINS, 'What is White Privilege, Really?' (2018) Issue 60, Teaching Tolerance $<$ https://www. tolerance.org/magazine/fall-2018/what-is-white-privilege-really> accessed 6 June 2020.

${ }^{88} \mathrm{cf}$ Central Park Five (n 78). Donald Trump: "I want to hate these murderers and I always will. I am not looking to psychoanalyse or understand them, I am looking to punish them."

${ }^{89}$ TERINA ALLEN, ' 3 Things Amy Cooper Did in Central Park to Damage Her Reputation and Career' Forbes (29 May 2020) <https://www.forbes.com/sites/terinaallen/2020/05/29/3-things-amy-cooper-did-incentral-park-that-destroyed-her-life/\#6abe2ba76198> accessed 6 June 2020.

${ }^{90}$ BILL HUTCHINSON, 'Police Chief Orders Probe in Handcuffing of Black Miami Doctor on front lines of Coronavirus Fight' ABC News (13 April 2020) <https://abcnews.go.com/US/police-chief-orders-probehandcuffing-black-miami-doctor/story?id=70111116> accessed 6 June 2020.

${ }^{91}$ MICHAEL WARREN, ET AL, 'Conservative Groups are Boosting the Anti-lockdown Protests - "I think the President wants this Country to get back to work' The Mercury News (21 April 2020) <https://www.mer curynews.com/2020/04/20/conservative-groups-are-boosting-the-anti-lockdown-protests/> accessed 5 June 2020.

${ }^{92}$ ELIZA RELMAN, 'Fox News Host Defended Anti-lockdown Protesters Who Called Michigan's Governor a Nazi as They Displayed Confederate Flags and Swastikas' Business Insider (18 April 2020) <https://www. businessinsider.in/politics/world/news/fox-news-host-defended-anti-lockdown-protesters-who-calledmichigans-governor-a-nazi-as-they-displayed-confederate-flags-and-swastikas/articleshow/75225345.cms>
} 
Donald Trump, called them 'very good people' who were just 'angry', and advised the law enforcements and governors to treat them very kindly. ${ }^{93}$ This unduly favorable treatment triggers the memory of Martin Luther King Jnr., who rightly believed that the drafters of the First and Second Amendments' rights in 1789 and 1791 respectively, did not contemplate that Black people in America who first came in contact with concepts of human rights in the Thirteenth Amendment in 1865, will enjoy the right to protest, let alone bear arms. ${ }^{94}$

The support white Americans receive from the police is unarguably symbiotic in the sense that the police treat them with exceptional kindness and empathy, even offering them water ${ }^{95}$ and hamburger ${ }^{96}$ in the process of arrest for capital offences, or hugged tightly by a judge and the victim's family shortly after conviction as was shown to Amber Guyger. ${ }^{97}$ Perhaps, this level of sympathy and compassion ought to be the model of how every human being in America should be treated by their fellow citizens, the police and justice system. In reciprocating the favor underlying this police partiality, many white Americans try not to criticize the police no matter what the latter have done; they try to rationalize and make excuses on their behalf as Michael Bloomberg did after the wrongful killing of Sean Bell by the NYPD officers. ${ }^{98}$ Generally, and perhaps understandably, it is difficult for white Americans enjoying their white privileges, e.g., not being arrested for fatally shooting Almaud Arbery, until after 74 days following Twitter and Facebook outcries, ${ }^{99}$ to begrudge the same police that feed them regularly with these privileges, and since they do not recurrently lose family members due to wrongful arrests and extra judicial killings by the police, even when such family members were resting or sleeping in the comfort of their homes as were the cases of Atatiana Jefferson, ${ }^{100}$ Botham

\footnotetext{
${ }^{93}$ In response to the protest, Trump tweeted that "these are very good people, but they are angry. They want their lives back again, safely!” ANNE GEARAN \& JOHN WAGNER, 'Trump Calls Michigan Protesters "very good people" Boston (2 May 2020) <https://www.boston.com/news/national-news-2/2020/05/02/ trump-calls-michigan-protesters-very-good-people> accessed 7 June 2020.

94 cf MARTIN LUTHER KING JNR (n 32). Trevor Noah, Commentary on the Police Shooting of Mr. Emantic Bradford Jr. The Daily Show.

${ }^{95} \mathrm{cf}$ Sebastian Arzadon (n 50).

${ }^{96}$ cf Dylann Roof (n 51).

${ }^{97}$ SARAH MERVOSH, 'Amber Guyger's Judge Gave Her a Bible and a Hug. Did That Cross a Line?' New York Times (4 October 2019) < https://www.nytimes.com/2019/10/04/us/amber-guyger-judge-tammykemp-hug.html> accessed 8 June 2020.

${ }^{98}$ Michael Bloomberg, the New York City mayor at that time said "We know that the officers on the scene had reason to believe an altercation involving a firearm was about to happen and were trying to stop it," JULIAN BURGER, 'New York on Edge as Police Kill Unarmed Man in Hail of 50 Bullets on His Wedding Day' The Guardian (7 November 2006) <https://www.theguardian.com/world/2006/nov/27/usa. julianborger>; EMILY TAMKIN, 'How White America Excuses Its Own Violence' NewStatesman (29 May 2020) <https://www.newstatesman.com/world/2020/05/minneapolis-protests-george-floyd-killing-blackwhite-america-race-riots> accessed 8 June 2020.

99 JANELLE GRIFFITH, 'Ahmaud Arbery Shooting: A Timeline of the Case' NBC News (12 May 2020) $<$ https://www.nbcnews.com/news/us-news/ahmaud-arbery-shooting-timeline-case-n1204306> accessed 7 June 2020.

${ }^{100}$ ERIK ORTIZ, 'Forth Worth Police Officer Who Fatally Shot Atatiana Jefferson Indicted on Murder Charge' NBC News (21 December 2019) <https://www.nbcnews.com/news/us-news/fort-worth-policeofficer-who-fatally-shot-atatiana-jefferson-indicted-n1105916> accessed 7 June 2020.
} 
Jean, ${ }^{101}$ Breonna Taylor, ${ }^{102}$ etc.,: in truth lack of such bitter experiences make it difficult for white Americans to be in Black people's shoes, or empathize, or get truly disgusted and angry at these countless incidents of police brutality.

Instead, many white Americans appear to have been generally socialized to see police killings from the mainstream lenses, such that when a white police officer kills a Black person, it is thought that he most likely killed him in self-defense: ${ }^{103}$ i.e. the officer was most likely threatened by the Black person, even when the latter was moving away from the police officer as was in Walter Scott's case ${ }^{104}$ or strictly complying with instructions as was in Philando Castile's case. ${ }^{105}$ They have also been socialized to cite some false equivalent and isolated incidents to whittle the truth that accrues from the repeated pattern of black killings. For instance, the BlackLivesMatter ${ }^{106}$ movement is quelled by white supremacists with AllLivesMatter, WhiteLivesMatter, and BlueLivesMatter movements, which purport to deny the real issues of systemic injustice and inequality that Black people in America suffer and genuinely complain about.

However, if a black person kills a white policeman in the heat of passion, it is largely seen as murder and the entire justice system ensures that a life sentence is given, with the ridiculous possibility of 'serving an additional 38 years after death', as was the case with Tremaine Wilbourn. ${ }^{107}$ If a black person kills another black person, it is considered as a 'gang fight' and good for society since they are helping the system to get rid of themselves. ${ }^{108}$ If a non-white Muslim kills a white person for whatever reason,

${ }^{101}$ TOM DART, 'Amber Guyger Guilty of Murdering Black Neighbor Botham Jean in His Own Home' The Guardian (1 October 2019) <https://www.theguardian.com/us-news/2019/oct/01/amber-guyger-texasdallas-jury-botham-jean> accessed 7 June 2020.

${ }^{102}$ VICTORIA ALBERT, '911 Call from Breonna Taylor's Shooting Death Released: “Somebody Kicked in the Door and Shot My Girlfriend' CBS News (29 May 2020) <https:/www.cbsnews.com/news/breonnataylor-kenneth-walker-911-call-police-shooting/> accessed 7 June 2020.

${ }^{103}$ BENJAMIN WALLACE-WELLS, 'Police Shootings, Race, and the Fear Defense' The New Yorker (12 July 2016) <https:/www.newyorker.com/news/benjamin-wallace-wells/police-shootings-race-and-thefear-defense $>$ accessed 6 June 2020.

${ }^{104}$ AMANDA HOLPUCH \& OLIVER LAUGHLAND, 'Michael Slager Fired from South Carolina Police Force After Killing of Walter Scott' The Guardian (8 April 2015) <https://www.theguardian.com/usnews/2015/apr/08/michael-slager-south-carolina-officer-walter-scott-fired $>$ accessed 8 June 2020.

${ }^{105}$ CIARA MCCARTHY, 'Philando Castile: Police Officer Charged with Manslaughter over Shooting Death’ The Guardian (16 November 2016) < https://www.theguardian.com/us-news/2016/nov/16/philandocastile-shooting-manslaughter-police-jeronimo-yanez> accessed 7 June 2020.

106 The official website of BLACK LIVES MATTER $<$ https://blacklivesmatter.com/>

107 'Tremaine Wilbourn was sentenced to an additional 38 years on top of a life sentence for killing a Memphis Police Officer Sean Bolton': LINDA MOORE, ‘Tremaine Wilbourn Gets 38 Years Added to Life Sentence in Slaying of MPD Officer Sean Bolton’ Commercial Appeal (17 December 2018) <https://www. commercialappeal.com/story/news/2018/12/17/memphis-police-killing-tremaine-wilbourn-gets-38-yearsadded-life-sentence/2281111002/> accessed 8 June 2020.

108 ANTHONY BRAGA \& ROD BRUNSON, "The Police and Public Discourse on "Black-on-Black" Violence', New Perspective in Policing, Harvard Kennedy School (May 2015) <https://www.hks.harvard. edu/sites/default/files/centers/wiener/programs/pcj/files/PoliceandPublicDiscourseBlackonBlackViolence. pdf $>$ accessed 7 June 2020. 
justified or not, it is typically considered an act of terror, and the killer, perhaps a native born American, is automatically labelled a terrorist, with the accompanying threat to deport his family members and friends. ${ }^{109}$

Conversely, where for example, a white person walked into a black church and murdered the worshippers, ${ }^{110}$ he was assisted by the mainstream media with showers of pity, designating him a lone wolf that was mentally ill, thus shifting the focus to mental incapacity and an appeal for compassionate treatment rather than hate in such a difficult moment of his life. ${ }^{111}$ The mainstream media's regular plea of mental ill-health when a white person commits a heinous crime is perhaps aimed at influencing the jury during trial to tamper justice with mercy. White Americans constitute about $76.5 \%{ }^{112}$ of the total population and a significant percentage of them see issues from the above lenses, and since they constitute more than $80 \%$ of the entire police force and justice system, ${ }^{113}$ and own $80 \%$ of the American wealth, ${ }^{114}$ it becomes clearer why the police have a large fan base that drum and cheer them up from the sidelines no matter what they do. This level of white privilege, further showcased in the key cases below, is exceedingly oppressive to Black people and other racial minorities, and thus highly unacceptable from the human rights and ethical standpoints.

\subsection{A few illustrative cases of police brutality against black people in America between 1991 - 2020}

\subsubsection{Rodney King (1991)}

On 3 March 1991, Rodney King was unarmed when he was violently beaten by 14 police officers of the Los Angeles Police Department. ${ }^{115}$ A civilian recorded the violent incident and sent it to the media. At a press conference, Los Angeles police chief, Daryl Gates, admitted that striking Mr. King 56 times with a baton and dumping about 50,000 volts on his body was an excessive use of force and promised to discipline

\footnotetext{
${ }^{109}$ LACY GRAY, 'Muslim Bashing in the Wake of Boston Bombing' National Geographic News (26 April 2013) <https://www.nationalgeographic.com/news/2013/4/130426-boston-marathon-bombing-racism-hate -anti-arab-muslim-tamerlan-dzokhar-tsarnaev/> accessed 7 June 2020.

110 cf Dylann Roof (n 51).

${ }^{111}$ GLENN SMITH \& JENNIFER HAWES, 'Unsealed Documents Shed Light on Dylann Roof's Mental Health Issues’ The Post and Courier (2 February 2017) < https://www.postandcourier.com/church_shooting/ unsealed-documents-shed-light-on-dylann-roofs-mental-health-issues/article_404a01bc-e959-11e6-ad240f32fef $2 \mathrm{c} 5 \mathrm{bb} . \mathrm{html}>$ accessed 8 June 2020.

112 UNITED STATES CENSUS BUREAU, 'The Population of White People in the United States' (2019) $<$ https://www.census.gov/quickfacts/fact/table/US/IPE120218> accessed 8 June 2020.

113 JEREMY ASHKENAS, ET AL, 'The Race Gap in America's Police Departments' New York Times (3 September 2014) < https://www.nytimes.com/interactive/2014/09/03/us/the-race-gap-in-americas-police-de partments.html?mtrref=www.google.com\&gwh=769DCE1705226C89783CA65B7FADE620\&gwt=pay\& assetType $=$ PAYWALL $>$ accessed 6 June 2020.

114 cf Chuck Collins, et al, (n 36).

115 MAEVE RESTON, 'Rodney King Shot While Riding Bike' Los Angeles Times (30 November 2007) $<$ https://www.latimes.com/archives/la-xpm-2007-nov-30-me-king30-story.html > accessed 8 June 2020.
} 
the officers involved. ${ }^{116}$ Four officers out of the 14 were charged, three of them were acquitted, and the jury could not reach a verdict for the fourth. ${ }^{117}$ The acquittals sparked an outraged among the Black community who started the '1992 Los Angeles riots' that lasted for six days with a lot of casualties until quelled by the California Army National Guard, the U.S. Army, and the Marine Corps. After this, the four officers were retried in a federal district court and two out of the four charged were found guilty and imprisoned for 2.5 years. ${ }^{118}$ In a separate suit, King was awarded $\$ 3.8$ million by the city of Los Angeles. ${ }^{119}$ King later published his memoir in 2012 and was found dead two months afterward in his swimming pool. ${ }^{120}$ The coroner's autopsy showed the presence of alcohol and drugs in his system and concluded that these and his heart condition likely led to his accidental drowning. ${ }^{121}$

\subsubsection{Amadou Diallo (1999)}

He was black, shot and killed by four plain-clothed policemen who later claimed that they mistook him for a rape suspect, an incident that occurred a year earlier. ${ }^{122}$ The officers fired 41 shots, 19 of which struck Diallo (unarmed) outside his apartment. The officers were charged with second degree murder in Albany but were acquitted at trial. $^{123}$

\subsubsection{Sean Bell (2006)}

He was black and unarmed when he was fatally shot on the eve of his wedding during a bachelor's party. The NYPD officers in plain cloths fired a total of 50 rounds at Bell's car which killed him. ${ }^{124}$ Eyewitness accounts of what happened were contradicted by the police's account which manipulated the facts. ${ }^{125}$ Three out of five detectives that carried out the shooting were charged for first and second degree assault, and a second degree assault of reckless endangerment; they were all found not guilty.

116 BENJAMIN HOUSTON, 'The 1992 LA Riots' History Extra (2 June 2020) <https://www. historyextra.com/period/20th-century/los-angeles-la-riots-rodney-king-caused-died-cost-consequences/>; ASSOCIATED PRESS, 'Rodney King Riots: Timeline and Key Events' The Associated Press News (27 April 2017) accessed 8 June 2020.

117 ibid.

118 ibid.

119 ibid.

120 ibid.

121 ibid.

122 CHRISTIAN RED, 'Years Before Black Lives Matter, 41 Shots Killed Him' New York Times (19 July $2019)<$ https:/www.nytimes.com/2019/07/19/nyregion/amadou-diallo-mother-eric-garner.html $>$ accessed 8 June 2020.

123 ibid.

124 JULIAN BORGER, 'New York on Edge as Police Kill Unarmed Man in Hail of 50 Bullets on His Wedding Day' The Guardian (7 November 2006) <https://www.theguardian.com/world/2006/nov/27/usa. julianborger $>$ accessed 8 June 2020 .

125 ibid. 


\subsubsection{Oscar Grant (2009)}

He was black and unarmed at the time of his arrest for a suspected fight. ${ }^{126}$ One of the police officers threw him on the ground face-down and kneeled at the back of his head, while his colleague, Johannes Mehserle, a white police officer, drew out his gun and shot him fatally in the back. The video of the shooting went viral and Mehserle was arrested, charged for second degree murder, but was found guilty of only involuntary manslaughter, and not guilty of the other charges for murder and voluntary manslaughter. ${ }^{127} \mathrm{He}$ was sentenced to 2 years but later released on parole after serving 11 months in Los Angeles County Jail, where he was held in a private cell for his safety. ${ }^{128}$ The Bart Police later settled Grant's family with $\$ 2.8$ million. ${ }^{129}$

\subsubsection{Eric Garner (2014)}

He was accused of selling single cigarettes from packs without tax stamps. ${ }^{130}$ Daniel Pantaleo, a white officer of NYPD, tackled Mr. Garner down and put him in a chokehold during the arrest. About three other officers, Mr. Pantaleo's colleagues, helped to pin Garner to the ground, and his plea that he could not 'breathe' was ignored. The medical examiner ruled that his death was a homicide but also cited 'asthma and heart disease' as contributory factors. ${ }^{131}$ The Richmond County grand jury decided not to indict Mr. Pantaleo. ${ }^{132}$ This sparked a nationwide outrage leading to about 50 demonstrations on the streets of America. The New York City settled for \$5.9 million with Mr. Garner's family. ${ }^{133}$ The US Department of Justice in 2019, refused to bring any criminal charges against Pantaleo, ${ }^{134}$ and only his employment was recommended to be terminated after five years of intentionally killing Mr. Garner. ${ }^{135}$

\footnotetext{
126 SAM LEVIN, 'Officer Punched Oscar Grant and Lied About Facts in 2009 Killing, Records Show' The Guardian (2 May 2019) <https://www.theguardian.com/us-news/2019/may/02/officer-punched-oscargrant-and-lied-about-facts-in-2009-killing-records-show> accessed 7 June 2020.

${ }^{127}$ EWEN MACASKILL, 'Oscar Grant Shooting: Officer Found Guilty of Involuntary Manslaughter' The Guardian (9 July 2010) <https://www.theguardian.com/world/2010/jul/09/oscar-grant-oakland-policeshooting $>$ accessed 10 June 2020.

${ }^{128}$ cf Daily Mail Reporter (n 29).

129 ibid.

${ }^{130}$ Eric Garner's Video, 'I Can’t Breathe': Eric Garner Put in Chokehold by NYPD Officer' The Guardian (4 December 2014) <https://www.theguardian.com/us-news/video/2014/dec/04/i-cant-breathe-eric-garnerchokehold-death-video> accessed 7 June 2020.

${ }^{131}$ ALI WINSTON, 'Medical Examiner Testifies Eric Garner Died of Asthma Caused by Officer's Chokehold' New York Times (15 May 2019) <https://www.nytimes.com/2019/05/15/nyregion/eric-garner-death-danielpantaleo-chokehold.html $>$ accessed 7 June 2020.

${ }^{132}$ ANDREW SIFF, ET AL, 'Grand Jury Declines to Indict NYPD Officer in Eric Garner Chokehold Death' NBC New York (4 December 2014) <https://www.nbcnewyork.com/news/local/grand-jury-decision-ericgarner-staten-island-chokehold-death-nypd/1427980/> accessed 8 June 2020.

${ }^{133}$ DAVID GOODMAN, 'Eric Garner Case Is Settled by New York City for \$5.9 Million' New York Times (14 July 2015) <https://www.nytimes.com/2015/07/14/nyregion/eric-garner-case-is-settled-by-new-yorkcity-for-5-9-million.html $>$ accessed 8 June 2020.

${ }^{134}$ KATIE BENNER, 'Eric Garner's Death Will Not Lead to Federal Charges for NYPD Officer' New York Times (16 July 2019) <https:/www.nytimes.com/2019/07/16/nyregion/eric-garner-case-death-danielpantaleo.html $>$ accessed 7 June 2020.

135 ibid.
} 


\subsubsection{Michael Brown (2014)}

He was black and unarmed, with his hands raised at the time of the multiple fatal shots at him by a white police officer, Mr. Darren Wilson, in Ferguson. However, the investigations report by the FBI declared that there was no evidence that Brown raised his hands and warned the police not to shoot him. ${ }^{136}$ The St. Louis County grand jury decided ${ }^{137}$ not to prosecute Mr. Wilson and the US Department of Justice cleared Mr. Wilson of all civil rights violations in the shooting. ${ }^{138}$ There were nationwide protests disapproving of the unjustifiable lethal force used on Brown and other similar cases of black shootings. ${ }^{139}$

\subsubsection{Antwon Rose (2018)}

He was black and unarmed at the time he was fatally shot by a white policeman, Michael Rosfeld, in East Pittsburg. ${ }^{140}$ Mr. Rosfeld was charged with criminal homicide, but after a 4-day trial, he was acquitted on all counts. ${ }^{141}$ There were many demonstrations objecting to the acquittal verdict, the longest of which lasted for three days before dying out.

\subsubsection{George Floyd (2020)}

George Floyd, was a black man, and unarmed when he was being arrested by the police for a suspected offence of forgery. Contrary to the police report accusing him of resisting arrest, video records from nearby CCTVs showed that Mr. Floyd was calm and cooperative during the arrest. However, he was thrown to the ground and pinned strongly by two of the officers, another officer helped to stave off any possible interventions by onlookers, which provided Derek Chauvin, a former white police office, the comfort to use his knee to pin Floyd's neck on the tarmac for about nine minutes, the last 3 minutes being after Floyd was no longer responsive. ${ }^{142}$

Throughout the kneeling on Floyd's neck, Chauvin pocketed his hand with nonchalance, a significant indication that he was fully aware of his actions and what he wanted to achieve. Floyd repeatedly pleaded that he could not 'breathe', pleaded

\footnotetext{
136 JAKE HALPERN, 'The Cop Darren Wilson was not indicted for shooting Michael Brown. Many People question whether Justice was done’ The New Yorker (3 August 2015) <https:/www.newyorker.com/ magazine/2015/08/10/the-cop> accessed 7 June 2020.

137 ibid.

138 ibid.

139 ibid.

${ }^{140}$ ADEEL HASSAN, ‘Antwon Rose Shooting: White Police Officer Acquitted in Death' New York Times (22 March 2019) <https://www.nytimes.com/2019/03/22/us/antwon-rose-shooting.html> accessed 7 June 2020 .

141 ibid.

${ }^{142}$ EVAN HILL, ET AL, '8 Minutes and 46 Seconds: How George Floyd Was Killed in Police Custody' New York Times (31 May 2020) <https://www.nytimes.com/2020/05/31/us/george-floyd-investigation.html> accessed 8 June 2020.
} 
for water, called on his dead mother, and a little opportunity to stand a bit. Bystanders who were filming the incident pleaded with Mr. Chauvin for mercy but he would not listen to them. At the time of writing this paper (June 2020), Chauvin has been charged with a second degree murder following a nationwide protest, while the other three officers have been charged for "aiding and abetting second-degree murder and aiding and abetting second-degree manslaughter." 143 Meanwhile, Donald Trump through tweets and Rose Garden speeches helped to fuel the anger underlying the protests; he called the protesters thugs, looters, terrorists, and used the U.S. military to 'dominate' them. ${ }^{144}$

The forgoing cases of race-motivated killings and injustices against Black people prove that they are systemically being oppressed in America, even though in theory, they have a bundle of human rights and deemed equal with white people. The American Government has failed to adequately protect and provide for Black people the same way it protects and provides for their white counterparts, and for this reason, the Government is in fundamental breach of the social contract with Black people. ${ }^{145}$ In the circumstance, Black people ought not to be obligated in following the black-letter law and procedures toward showcasing their grievances over the breach of social contract; they ought to be discharged from further performance until the American Government can pay damages for the centuries of breach through sincere and sustainable justice reforms that truly ensure racial equality in America.

\section{The Metaphor of Hate: Private Prisons, Money Bail, and Profiteering Mass Incarceration Of Black Bodies}

\subsection{Reexamining the Thirteenth Amendment from a functional approach: the slave plantations reincarnated as the American prisons}

The Thirteenth Amendment to the American Constitution abolished slavery and involuntary servitude except in the context of punishment. ${ }^{146}$ Per capita, America imprisons its citizens more than any other country in the developed world ${ }^{147}$ with the

\footnotetext{
${ }^{143}$ BBC, 'George Floyd death: New Charges for All Four Sacked Officers' BBC News (3 June 2020) <https:// www.bbc.com/news/world-us-canada-52915019\#: :text=Derek\%20Chauvin $\% 20$ charged $\% 20$ with $\% 20$ murder\&text=Former\%20Minneapolis $\% 20$ police $\% 20$ officer $\% 20$ Derek $\% 20$ Chauvin $\% 2 \mathrm{C} \% 2044 \% 2 \mathrm{C} \% 20$ is $\% 20$ charged $\% 20$ with,combined $\% 20$ maximum $\% 2035 \% 2$ Dyear $\% 20$ sentence.> accessed 8 June 2020.

${ }^{144}$ BBC, 'George Floyd Death: Trump Threatens to send in Army to end Unrest' BBC News (2 June 2020) $<$ https://www.bbc.com/news/world-us-canada-52886736> accessed 8 June 2020.

145 cf Cavin Robinson (n 52).

${ }^{146}$ SHUAN KING, 'KING: How the 13th Amendment Didn't Really Abolish Slavery, but let it live on in U.S. Prisons' New York Daily News (21 September 2016) <https://www.nydailynews.com/news/national/ king-13th-amendment-didn-abolish-slavery-article-1.2801218> accessed 8 June 2020.

${ }^{147}$ ROB PICHETA \& HENRIK PETTERSON, 'American Police Shoot, Kill and Imprison more People than Other Developed Countries. Here's the Data' CNN (8 June 2020) <https://edition.cnn.com/2020/06/08/ us/us-police-floyd-protests-country-comparisons-intl/\#: :text=The $\% 20$ US $\% 20$ has $\% 20$ the $\% 20$ largest,populations\%20around\%20the\%20world\%20annually.> accessed 8 June 2020.
} 
assistance of a huge annual prison budget of $\$ 182$ billion, ${ }^{148}$ more than the annual budgets of many countries. Sometime in the 80's when American prisons became overcrowded, the Government started to outsource prison management to private entities, which have today grown to become multibillion corporations with their stocks quoted on the New York Stock Exchange. Two such successful corporations are CoreCivic (formerly the Corrections Corporation of America), ${ }^{149}$ and GEO Group ${ }^{150}$ with more than $\$ 3.7$ billion and $\$ 4.3$ billion of total worth, respectively.

To satisfy a few of the rationale behind imprisonment, such as 'reformation' and 'rehabilitation', ${ }^{151}$ prisoners, whether in state and federal-run prisons or in their privaterun counterparts must perform some menial tasks for little or no pay. The Thirteenth Amendment in 1865 abolished slavery; although it exempted 'involuntary servitude' in the context of punishment. ${ }^{152}$ Its drafters, perhaps, did not envisage that prisons will today be run by profit-making corporations. Thus, in its ideal sense, the Thirteenth Amendment is partially defeated because the progenies of those who opposed the Amendment during the time it was deliberated in Congress can continue to realize their ancestors' aspiration of enslaving Black people, if only they can trigger the 'punishment clause' in the Amendment to functionally achieve the 'involuntary servitude' of black bodies. ${ }^{153}$

Today in America, Black people are six times more likely to be incarcerated than white people. ${ }^{154}$ Viewed from the lens of 'Shareholder Primacy', ${ }^{155}$ corporations operate for the foremost purpose of making profits for their shareholders, and it is common knowledge that the private prisons in America quote enormous revenues and profits, and much of their revenue comes from the use of unpaid or underpaid prison labor under the guise of 'reformation and rehabilitations' of the prisoners. ${ }^{156}$ The uncomfortable issue here is that these prison corporations are paid by the American governments based on the number of inmates they harbor and manage. In other words, the more inmates a prison harbors, and

148 PETER WAGNER \& BERNADETTE RABUY, 'Following the Money of Mass Incarceration' Prison Policy Initiative (25 January 2017) < https://www.prisonpolicy.org/reports/money.html > accessed 8 June 2020.

${ }^{149}$ CORECIVIC, $<$ https://www.corecivic.com/>

${ }^{150}$ GEO GROUP INC., < https://www.geogroup.com/>

${ }^{151}$ CHRIS WEAVER \& WILL PURCELL, 'The Prison Industrial Complex: A Modern Justification for African Enslavement?' (1998) 41 Howard Law Journal 349, 349-50.

152 ibid.

${ }^{153}$ KAMAL GHALI, 'No Slavery Except as A Punishment for Crime: The Punishment Clause and Sexual Slavery’ (2008) 55 UCLA Law Review 607, 608 <https://www.uclalawreview.org/pdf/55-3-2.pdf> accessed 8 June 2020.

${ }^{154}$ BRUCE DRAKE, 'Incarceration Gap Widens Between Whites and Blacks' Pew Research Center (3 September 2013) <https:/www.pewresearch.org/fact-tank/2013/09/06/incarceration-gap-between-whitesand-blacks-widens/> accessed 8 June 2020.

155 JULIAN VELASCO, 'Shareholder Ownership and Primacy' (2010) University of Illinois Law Review 897, 944. <https://scholarship.law.nd.edu/law_faculty_scholarship/319>

${ }^{156}$ WHITNEY BENNS, 'American Slavery, Reinvented' The Atlantic (21 September 2015) <https://www. theatlantic.com/business/archive/2015/09/prison-labor-in-america/406177/> accessed 8 June 2020. 
the longer those inmates stay in the prisons, the more revenue that is guaranteed. From the profit perspective, this presumably triggers the competitive race for the mass acquisition of prisoners, perhaps, through some police-agents. ${ }^{157}$

In fact, for prison owners, long term prisoners functionally act as long term retainer-ship contracts with the governments, which enable them to reasonably forecast their revenues over a long period of time, thus making them attractive to potential credit or equity investors. Toward sustaining their regular stream of income from the governments, and also grow their corporate stocks, the ideal and most sought-after candidates for imprisonment are therefore young black men accused of murder, rape, and other crimes with long term sentences. Viewed from the profiteering lens, this perhaps explains why private prison corporations oppose death penalty, and financially contribute to the election campaigns of political candidates who will perpetuate their narrow interests, because for them, a goose is worth more alive than dead. ${ }^{158}$ This motive fundamentally differs from that of human rights activists seeking to abolish the death penalty on a prolife and ethical bases. This could further explain the numerous instances Black people were wrongfully accused by the police for rape and murder, but later through whistleblowing efforts, it was discovered that the police had exonerating pieces of evidence ab initio, but refused to make it available to the defense counsel. ${ }^{159}$

It appears that there is always the business question of where a sufficient number of prisoners will come from in order to sustain the income and profits of prison owners in America? This question is similar to the one asked in the $15^{\text {th }}$ century when America was newly 'discovered' and there was the business question of where to obtain free or cheap labor to cultivate sugarcane and cottons on its vast expanse of land? The answer was found in looting young Black people from Africa, ${ }^{160}$ just like the current generation of young Black people in America are being looted from their homes and streets into white owned prisons as money-making stocks. Functionally, there is a close resemblance between the involuntary servitude of Black people for the plantation owners before the Thirteenth Amendment and the involuntary servitude of Black people for prison owners in the post Thirteenth Amendment era, and just like slave plantations were outlawed, a similar approach is required to address their reincarnates - the American prisons.

Further, in comparison, just like there was a chain of middlemen in the Slave Trade era starting with the arrest and brutality of Black people in their homes and streets in Africa, to handcuffing them in chains and shipping them off to America where they became money-making stocks in the plantations, so also in the post Thirteenth Amendment

\footnotetext{
157 JOSEPH GOLDSTEIN \& ASHLEY SOUTHALL, ' I Got Tired of Hunting Black and Hispanic People' New York Times (9 December 2019) <https://www.nytimes.com/2019/12/06/nyregion/nyc-police-subwayracial-profiling.html $>$ accessed 6 June 2020.

${ }^{158}$ SCOTT SORIANO, 'Private Prisons are California Political Players' Capitol Weekly (7 September 2018)

$<$ https://capitolweekly.net/private-prisons-california-political-players/> accessed 7 June 2020.

159 cf CENTRAL PARK FIVE (n 78).

${ }^{160} \mathrm{cf}$ KHALIL MUHAMMAD (n 3).
} 
era, there is a chain of middlemen, starting with the arrest and brutality of Black people by the police, forcing them into police vehicles and beating or killing them for any little resistance, depositing them in police stations and functionally denying them bail due to high cash bonds, charging and obtaining long duration sentences through the aid of corrupt judges working for the common agenda, and finally incarcerating them in private prisons where they begin to make money for prison owners scrambling for a piece of the $\$ 182$ billion annual prison budget. ${ }^{161}$ Additionally, the involuntary labor of prisoners and their poor living conditions in order to save money out of the \$36, 299.25 annually budgeted for each prisoner by the U.S. government, ${ }^{162}$ all help to swell corporate stocks. ${ }^{163}$ Hypothetically, if the products emanating from this type of labor are exported, they stand to offend the tenets of the Word Trade Organization which bans the use of prison labor to enhance export performance. ${ }^{164}$

\subsection{Do American police officials and judges benefit from the mass incarceration of black people in America?}

There have been attempts to investigate whether judges, police officers, and influential people in the American justice system own stocks in prison and bail bond corporations. ${ }^{165}$ Such efforts have always been frustrated with a lot of rules that make obtaining and publishing the list of individual shareholders in these corporations very difficult. For example, CoreCivic, registered in the state of Maryland even though headquartered in Tennessee, enjoys the former's corporate law requirement that only a shareholder with $5 \%$ of stocks (about $\$ 200$ million in the case of CoreCivic) can request and peruse the list of shareholders. Similarly, under the law of Florida where GEO Group is registered, a shareholder is prohibited from distributing any information or record if the distribution differs from the purpose indicated during the time it was obtained from the corporation. ${ }^{166}$ There is a strong need to legislate against the possibility of judges, police officers, and key officers in the U.S. Justice Department, from directly or indirectly owning stocks in prison and bail corporations, and another legislation to make it possible for anyone to freely apply and obtain without delay, the list of shareholders of these corporations, as preliminary steps toward checkmating the corruption of the police and biases of judges vis-à-vis mass incarceration.

\footnotetext{
161 cf PETER WAGNER \& BERNADETTE RABUY (n 148).

162 United States Federal Register, 'Annual Determination of Average Cost of Incarceration' Prison Bureau (30 April 2018) <https://www.federalregister.gov/documents/2018/04/30/2018-09062/annualdetermination-of-average-cost-of-incarceration> accessed 20 October 2020.

163 JOE FASSLER \& CLAIRE BROWN, 'Prison Food Is Making U.S. Inmates Disproportionately Sick' The Atlantic (27 December 2017) <https://www.theatlantic.com/health/archive/2017/12/prison-food-sicknessamerica/549179/>; Tim Requarth, 'How Private Equity Is Turning Public Prisons Into Big Profits' The Nation (30 April 2019) <https://www.thenation.com/article/archive/prison-privatization-private-equityhig/>accessed 9 June 2020.

${ }^{164}$ Article XX(e) GATT < https://www.wto.org/english/res_e/booksp_e/gatt_ai_e/art20_e.pdf>

${ }^{165}$ GILLIAN WHITE, 'Who Really Makes Money Off of Bail Bonds?' The Atlantic (12 May 2017) <https:// www.theatlantic.com/business/archive/2017/05/bail-bonds/526542/> accessed 9 June 2020.

${ }^{166}$ ALEX FRIEDMANN, 'Who Owns Private Prison Stocks' Prison Legal News (31 July 2015) <https:// www.prisonlegalnews.org/news/2015/jul/31/who-owns-private-prison-stock/> accessed 8 June 2020.
} 
If the American Government is truly interested in ending the unjust and mass incarceration of Black people, it should encourage investigations and publication of findings on the allegations of judges and police officers receiving bribes from prison CEOs and controlling shareholders as compensation for bringing them large numbers of inmates. Alternatively, the private provision of bail and prison services should be abolished in America as one of the meaningful steps toward achieving the full effects of the Thirteenth Amendment for Black people, and a true therapy that will heal the open wound of slavery, by replacing hate with love and understanding amongst the races in America.

\section{The Metaphor of Violence}

\subsection{America's strong economy was partially built upon violence and loots}

As already hinted above, the 'discovery of America' in the $15^{\text {th }}$ century was followed by the looting of Black people from Africa as slaves to work without pay and enough rest in the plantations of slave owners. Africa's human and natural resources were looted and ferried to America for 400 years to develop the latter's economy. Of course, it is needless to emphasize that slavery was violent in nature, starting from the brutal arrests, bounding in chains, being packed like sardines in the tight cabins of slave ships, the raping and murdering of some captives, and a series of other nonchronicled criminal violence on Black people throughout the long and tortuous journeys to America. ${ }^{167}$ The violence and torture were so severe and unbearable that some of the slaves jumped into the Atlantic Ocean as a better alternative to what they were enduring on the ships. ${ }^{168}$ The slave market boomed because there were white American buyers waiting for the slave-stocks to arrive for onward use in their plantations. Black people became involuntary wealth creators that funded the rich and stupendous lifestyles of white Americans.

In the post slavery era, after the world had become a bit better organized with human rights such as those contained in the Universal Declaration of Human Rights, United Nations Charter, etc., America continued to hunt for resources abroad through neo colonization techniques ${ }^{169}$ and a direct use of violence to loot resources. ${ }^{170}$ Its main targets appear to be countries with rich crude oil resources, and this could explain why after the 9/11 incident wherein 15 out of the 19 terrorists involved came from Saudi Arabia, George Bush Jnr, against professional advice of the United Nations, started a war with Iraq instead of Saudi Arabia, under the pretext that Saddam Hussein among other charges of crime against humanity, also harbored weapons of mass destruction. In truth, there was no reasonable evidence to support this proposition other than being the U.S

\footnotetext{
${ }^{167}$ cf US HISTORY (n 6).

${ }^{168}$ MICHALE MARRIOT, 'Remembrance of Slave Ancestors Lost to the Sea' New York Times (19 June 1994) <https:/www.nytimes.com/1994/06/19/nyregion/remembrance-of-slave-ancestors-lost-to-the-sea. html $>$ accessed 9 June 2020.

${ }^{169} \mathrm{cf}$ (n 35).

${ }^{170} \mathrm{cf}$ ERIC BONDS (n 57).
} 
tactic in triggering Article 51 of the UN Charter. ${ }^{171}$ The motive for taking war to Iraq has sufficiently been linked by researchers to Iraqi's rich crude oil resources. ${ }^{172}$

A similar motivation underscored the war in Afghanistan, ${ }^{173}$ and the killing of Maummar Gaddafi in Libya, ${ }^{174}$ all of which have left these countries worse off following the reduction of their cities to rubbles with American boots and bombs. In order to legitimize the loots and violence, the leaders of these countries were accused of being dictators and America claimed it was embarking on humanitarian missions to save the people from their despotic leaders. Yet, in Africa, Asia, and Middle East, there are many countries with dictators but with no crude oil resources which did not attract America's empathy and military intervention. North Korea is governed by a dictator and has repeatedly threatened to nuke America, ${ }^{175}$ but no war was started with them toward removing the alleged weapons of mass destruction, perhaps, due to its lack of crude oil resources.

\subsection{The lack of majoritarian criticisms of America's violence and loots}

Within America, the Government continues to make money from the taxes of private prisons and bail bond corporations, and their oil-corporate citizens it has installed abroad to embezzle energy resources. None of the forgoing acts of violence and plundering by the American Government has received serious majoritarian condemnation or visible white protests on the streets to stop foreign and domestic violence and loots. This is presumably because a significant percentage of the wealth obtained from these loots are owned by white Americans, ${ }^{176}$ who are more interested in protecting their wealth and the sources they come from at the expense of human rights. This deafening silence invariably endorses and approves of the loots and other related acts of the American Government. Therefore, when Black people protest on the streets for the racist injustices they suffer, and consequently receive labels from white supremacists as being violent thugs and looters, it is submitted here that majority of these accusers are not truly opposed to violence, damage and theft of property given that their wealth is significantly built on such foundation. They oppose black protests maybe because the outcome affects or could affect their proprietary interests.

It is further submitted that street protests have been effective for Black people in America starting from the 1739 Stonno Rebellion to the Civil Rights movement in the 60 's, till date. This approach is therefore sufficiently tested, is effective, and a necessary

\footnotetext{
171 ibid.

${ }^{172}$ EWEN MACASKILL \& JULIAN BORGER 'Iraq War was Illegal and Breached UN Charter, Says Annan’ The Guardian (16 September 2004) <https://www.theguardian.com/world/2004/sep/16/iraq.iraq> accessed 9 June 2020.

173 cf ROD NORDLAND, ET AL, (n 58).

174 cf CHRISTOPHER DAVIDSON (n 59).

${ }^{175}$ MERIT KENNEDY, 'Amid Breakdown in Nuclear Talks, North Korea Threatens U.S. With 'Christmas Gift” NPR (3 December 2019) < https://www.npr.org/2019/12/03/784380119/amid-breakdown-in-nucleartalks-north-korea-threatens-u-s-with-christmas-gift> accessed 8 June 2020.

${ }^{176} \mathrm{cf}$ CHUCK COLLINS, ET AL, (n 37).
} 
tool in the good faith pursuit of racial equality and justice in America: it should not be stopped regardless of the unsolicited lectures from white supremacists on how best to protest.

\section{Conclusion: The Need for More Protests?}

The paper concludes by reiterating that the black-letter law or rights have not worked well for Black people in America because those who profit from the status quo continue to create systems that frustrate equal treatment and enjoyment of human rights. And in order to continue to profit from this unjust enrichment, the 'black body' has been made a metaphor for crime, violence, poverty and hate. In this era of Internet and globalization, there is more hope for Black people in America to reinvent the narrative and show the world these systemic ills and oppressions they suffer in abundance, as well as receive global empathy and solidarity as was exemplified by the global protests following George Floyd's death. This also means that if use of protests was effective toward achieving the Thirteenth Amendment and other important rights stemming from the Civil Rights movement in the non-digital era, then it has become more efficacious in the twenty-first century, wherein the prevalent use of smart phones enabled the world to eyewitness the horrific execution of George Floyd by a former white police officer.

It is highly disturbing that these atrocities are committed regularly, most times without punishment, and other times, with inadequate punishment of the wrongdoers, in a country that regularly praises itself as " $[\mathrm{t}]$ he guardians of freedom, preserving it for the benefit of the human race." 177 Black people in America should continue to learn how best to pierce through the deceptive veils of politicians, especially candidates for congressional seats who try to appease their feelings only during elections but do not sincerely engage afterward in fulfilling the promises that will end racial inequalities, perhaps due to regulatory capture. For Black people, a new model of politicking that does not rest strictly on political party affiliations, but on credible individuals who have sufficiently shown commitment to end the racial discrimination and police brutality of Black people in America.

Lastly, history teaches that true freedom is not given on a platter; it is fought for with sweat and blood, and the Black people in America are perhaps the most experienced freedom fighters in the world. The protests in the aftermath of George Floyd's death had already yielded some positive reforms and continue to inspire more reforms. Therefore, irrespective of any discouraging voices 'to take it easy,' simply because they are profiting from the status quo, it is hoped that more protests would be undertaken to achieve sustainable reforms that address police brutality, bail, and private prison systems, which until now have motivated and ensured the mass incarceration of Black people in America. Evidently, the positive outcomes from the protests and resistance against oppression and

\footnotetext{
${ }^{177}$ ANDREW JACKSON, 'Farewell Address of President Andrew Jackson' Miller Center (4 March 1837) $<$ https://millercenter.org/the-presidency/presidential-speeches/march-4-1837-farewell-address $>$ accessed 7 June 2020.
} 
police brutality in America have also been a vital source of inspiration to other marginalized peoples around the globe, for instance in Nigeria, where the youths have started to boldly raise their heads above the parapet and standing on their full height to challenge incidents of police brutality through peaceful protests. ${ }^{178}$

\section{REFERENCES}

ABC, 'Cops bought Burger King for Dylann Roof following his Arrest' Eyewitness News (23 June 2015) <https://abc7.com/dylann-roof-south-carolina-church-shootingemanuel-african-methodist-episcopal/801013/>

ADAM JOHNSON, 'How the Media Smears Black Victims' Los Angeles Times (30 March 2017) <https://www.latimes.com/opinion/op-ed/la-oe-johnson-black-victi m-20170330-story.html>

ADEEL HASSAN, 'Antwon Rose Shooting: White Police Officer Acquitted in Death' New York Times (22 March 2019) <https://www.nytimes.com/2019/03/22/us/ antwon-rose-shooting.html>

ADRIAN HORTON, 'John Oliver: When Trump uses the word Thugs, you know what it's Code for' The Guardian (1 June 2020) <https:/www.theguardian.com/culture/ 2020/jun/01/john-oliver-when-trump-uses-thugs-code-racism-george-floyd-pro tests>

ALEX FRIEDMANN, 'Who Owns Private Prison Stocks' Prison Legal News (31 July 2015) <https://www.prisonlegalnews.org/news/2015/jul/31/who-owns-private-pri son-stock/>

ALFRED COTTON, 'Do Black Lives Matter in American Mainstream News Media? Two Case Studies of Police-involved Shootings of Black Men explaining a racist Media Environment' (DPhil thesis, 2016) < https://uknowledge.uky.edu/comm_etds/52>

ALI WINSTON, 'Medical Examiner Testifies Eric Garner Died of Asthma Caused by Officer's Chokehold' New York Times (15 May 2019) <https://www.nytimes. com/2019/05/15/nyregion/eric-garner-death-daniel-pantaleo-chokehold.html>

AMANDA HOLPUCH \& OLIVER LAUGHLAND, 'Michael Slager Fired from South Carolina Police Force After Killing of Walter Scott' The Guardian (8 April 2015) $<$ https://www.theguardian.com/us-news/2015/apr/08/michael-slager-south-caroli na-officer-walter-scott-fired $>$

ANDRE PERRY, 'You Can't Have an Equitable Economy While Ignoring Police Violence' City Lab (28 March 2019) < https://www.citylab.com/perspective/2019/03/pittsbu rgh-police-shooting-antwon-rose-jobs-economy/585841/>

\footnotetext{
${ }^{178}$ NEIL MUNSHI, 'Youth of Nigeria Force Buhari's Hand as Anger at Police Brutality Boils Over' Financial Times (15 October 2020) <https://www.ft.com/content/777c9f4e-e071-49c8-98f6-abcd2e8b0d76> accessed 21 October 2020.
} 
ANDREW JACKSON, 'Farewell Address of President Andrew Jackson' Miller Center (4 March 1837) <https://millercenter.org/the-presidency/presidential-speeches/ march-4-1837-farewell-address $>$

ANDREW SIFF, ET AL, 'Grand Jury Declines to Indict NYPD Officer in Eric Garner Chokehold Death' NBC New York (4 December 2014) < https://www.nbcnewyork. com/news/local/grand-jury-decision-eric-garner-staten-island-chokehold-deathnypd/1427980/>

ANNE GEARAN \& JOHN WAGNER, 'Trump Calls Michigan Protesters 'very good people" Boston (2 May 2020) <https://www.boston.com/news/national-news -2/2020/05/02/trump-calls-michigan-protesters-very-good-people>

ANTHONY BRAGA \& ROD BRUNSON, 'The Police and Public Discourse on "Blackon-Black" Violence', New Perspective in Policing, Harvard Kennedy School (May 2015) < https://www.hks.harvard.edu/sites/default/files/centers/wiener/programs/ pcj/files/PoliceandPublicDiscourseBlackonBlackViolence.pdf $>$

ANTONIA JUHASZ, 'Why the War in Iraq was fought for Big Oil' CNN (15 April 2003) $<$ https://edition.cnn.com/2013/03/19/opinion/iraq-war-oil-juhasz/index.html>

ARTICLE XX(E) GATT <https://www.wto.org/english/res_e/booksp_e/gatt_ai_e/art2 0 e.pdf>

ASSOCIATED PRESS, 'Autopsy Report Shows Floyd Tested Positive for Coronavirus' US News (4 June 2020) <https://www.usnews.com/news/us/articles/2020-06-03/ autopsy-report-shows-floyd-had-tested-positive-for-covid-19>

ASSOCIATED PRESS, 'Rodney King Riots: Timeline and Key Events' The Associated Press News (27 April 2017).

AVA KOFMAN, ET AL, 'White Supremacy Gateway to the American Mind' The Atlantic (7 April 2020) <https://www.theatlantic.com/technology/archive/2020/04/whitesupremacys-gateway-to-the-american-mind/609595/>

BBC, 'Central Park Five: The True Story Behind When They See Us' BBC News (12 June 2019) <https://www.bbc.com/news/newsbeat-48609693>

BBC, 'George Floyd death: New Charges for All Four Sacked Officers' BBC News (3 June 2020) <https://www.bbc.com/news/world-us-canada-52915019\#: :text=Derek\%20Chauvin $\% 20$ charged $\% 20$ with $\% 20$ murder\&text=Former $\% 20$ Minneapolis\%20police\%20officer\%20Derek\%20Chauvin\%2C\%2044\%2C\%20 is $\% 20$ charged $\% 20$ with,combined $\% 20$ maximum $\% 2035 \% 2$ Dyear $\% 20$ sentence.>

BBC, 'George Floyd Death: Trump Threatens to send in Army to end Unrest' BBC News (2 June 2020) <https://www.bbc.com/news/world-us-canada-52886736>

BBC, 'George Floyd: 'Pandemic of racism' led to His Death, Memorial Told' BBC News (5 June 2020) <https://www.bbc.com/news/world-us-canada-52928304> 
BBC, 'Maryland Trio Set Free After Being Wrongfully Jailed for 36 Years' BBC News (26 November 2019) <https://www.bbc.com/news/world-us-canada-50557396>

BEN CRUMP, 'I Believe Black Americans Face a Genocide. Here's Why I Choose that Word' The Guardian (15 November 2019) <https://www.theguardian.com/ commentisfree/2019/nov/15/black-americans-genocide-open-season>

BENJAMIN HOUSTON, 'The 1992 LA Riots' History Extra (2 June 2020) < https://www. historyextra.com/period/20th-century/los-angeles-la-riots-rodney-king-causeddied-cost-consequences/>

BENJAMIN WALLACE-WELLS, 'Police Shootings, Race, and the Fear Defense' The New Yorker (12 July 2016) <https://www.newyorker.com/news/benjamin-wallacewells/police-shootings-race-and-the-fear-defense>

BERNADETTE RABUY \& DANIEL KOPF, 'Detaining the Poor: How Money Bail perpetuates an endless Cycle of Poverty and Jail Time' Prison Policy Initiative (10 May 2016) <https://www.prisonpolicy.org/reports/incomejails.html>

BILL HUTCHINSON, 'Police Chief Orders Probe in Handcuffing of Black Miami Doctor on front lines of Coronavirus Fight' ABC News (13 April 2020) <https:// abcnews.go.com/US/police-chief-orders-probe-handcuffing-black-miami-doctor/ story? $\mathrm{id}=70111116>$

BLACK LIVES MATTER < https://blacklivesmatter.com/>

BRIAN WHITAKER, 'Fueling the Status Quo' The Guardian (5 April 2004) <https:// www.theguardian.com/world/2004/apr/05/worlddispatch.oil\#maincontent>

BRUCE DRAKE, 'Incarceration Gap Widens Between Whites and Blacks' Pew Research Center (3 September 2013) <https://www.pewresearch.org/fact-tank/2013/09/06/ incarceration-gap-between-whites-and-blacks-widens/>

CALVINJOHN SMILEY \& DAVID FAKUNLE, "From "brute" to "thug:" The Demonization and Criminalization of Unarmed Black Male Victims in America' (2016) 26 Journal of Human Behavior in the Social Environment, 2-3. <https:// www.tandfonline.com/doi/full/10.1080/10911359.2015.1129256>

CAVIN ROBINSON, 'Social Contract Theory, African American, Slave Narratives, and the Reconstruction of Early Modern Conceptions of Political Freedom' (DPhil thesis, DePaul University 2011) <https://via.library.depaul.edu/cgi/viewcontent. cgi?referer=https://www.google.com/\&httpsredir=1\&article=1082\&context=etd $>$

CHRIS WEAVER \& WILL PURCELL, 'The Prison Industrial Complex: A Modern Justification for African Enslavement?' (1998) 41 Howard Law Journal 349, 349.

CHRISTIAN RED, 'Years Before Black Lives Matter, 41 Shots Killed Him' New York Times (19 July 2019) <https://www.nytimes.com/2019/07/19/nyregion/amadoudiallo-mother-eric-garner.html $>$ 
CHRISTOPHER DAVIDSON, 'Why was Muammar Qadhafi Really Removed?' (2017) 24(4) Middle East Policy, 91-116.

CHUCK COLLINS, ET AL, 'The Racial Wide Divide Report' Institute for Policy Studies (2019) $11<$ https://inequality.org/wp-content/uploads/2019/01/IPS_RWD-Report_ FINAL-1.15.19.pdf $>$

CIARA MCCARTHY, 'Philando Castile: Police Officer Charged with Manslaughter over Shooting Death' The Guardian (16 November 2016) < https://www.theguardian. com/us-news/2016/nov/16/philando-castile-shooting-manslaughter-policejeronimo-yanez>

CORECIVIC, $<$ https://www.corecivic.com/>

CORY COLLINS, 'What is White Privilege, Really?' (2018) Teaching Tolerance, Issue 60 $<$ https://www.tolerance.org/magazine/fall-2018/what-is-white-privilege-really>

DAILY MAIL REPORTER, 'Former Police Officer who killed Unarmed Black Train Passenger is Released from Jail After Serving Just 11 Months' Mail Online (13 June 2011) < https://www.dailymail.co.uk/news/article-2003074/Johannes-Mehserlekilled-Oscar-Gran-released-jail-serving-11-months.html>

DAVID GOODMAN, 'Eric Garner Case Is Settled by New York City for \$5.9 Million' New York Times (14 July 2015) <https://www.nytimes.com/2015/07/14/nyregion/ eric-garner-case-is-settled-by-new-york-city-for-5-9-million.html>

DAVID OLUSOGA, 'The History of British Slave Ownership has been Buried: Now Its Scale can be revealed' The Guardian (London, 12 July 2015) $<$ https://www .theguardian.com/world/2015/jul/12/british-history-slavery-buried-scale-revealed>

ELIZA RELMAN, 'Fox News Host Defended Anti-lockdown Protesters Who Called Michigan's Governor a Nazi as They Displayed Confederate Flags and Swastikas' Business Insider (18 April 2020) <https://www.businessinsider.in/politics/ world/news/fox-news-host-defended-anti-lockdown-protesters-who-calledmichigans-governor-a-nazi-as-they-displayed-confederate-flags-and-swastikas/ articleshow/75225345.cms>

EMILY TAMKIN, 'How White America Excuses Its Own Violence' NewStatesman (29 May 2020) <https://www.newstatesman.com/world/2020/05/minneapolisprotests-george-floyd-killing-black-white-america-race-riots $>$

ERIC BONDS, 'Assessing the Oil Motive After the U.S. War in Iraq' (2013) 25:2 Peace Review, 291-298, DOI: <10.1080/10402659.2013.785769>

ERIC GARNER'S VIDEO, 'I Can't Breathe': Eric Garner Put in Chokehold by NYPD Officer' The Guardian (4 December 2014) <https://www.theguardian.com/usnews/video/2014/dec/04/i-cant-breathe-eric-garner-chokehold-death-video>

ERIK ORTIZ, 'Forth Worth Police Officer Who Fatally Shot Atatiana Jefferson Indicted on Murder Charge' NBC News (21 December 2019) <https://www.nbcnews 
.com/news/us-news/fort-worth-police-officer-who-fatally-shot-atatiana-jefferson -indicted-n1105916>

EVAN HILL, ET AL, ' 8 Minutes and 46 Seconds: How George Floyd Was Killed in Police Custody' New York Times (31 May 2020) <https://www.nytimes.com/2020/05/31/ us/george-floyd-investigation.html>

EWEN MACASKILL \& JULIAN BORGER Iraq War was Illegal and Breached UN Charter, Says Annan' The Guardian (16 September 2004) <https://www. theguardian.com/world/2004/sep/16/iraq.iraq>

EWEN MACASKILL, 'Oscar Grant Shooting: Officer Found Guilty of Involuntary Manslaughter' The Guardian (9 July 2010) < https://www.theguardian.com/ world/2010/jul/09/oscar-grant-oakland-police-shooting>

FREDERICK DOUGLASS, 'British Influence on the Abolition Movement in America' An Address Delivered in Paisley (Scotland, 17 April 1846) < https://glc.yale.edu/ british-influence-abolition-movement-america $>$

FREE THE SLAVES < https://www.freetheslaves.net/about-slavery/slavery-in-history/>

GEO GROUP INC., <https://www.geogroup.com/>

GILLIAN WHITE, 'Who Really Makes Money Off of Bail Bonds?' The Atlantic (12 May 2017) <https://www.theatlantic.com/business/archive/2017/05/bailbonds/526542/>

GLENN SMITH \& JENNIFER HAWES, 'Unsealed Documents Shed Light on Dylann Roof's Mental Health Issues' The Post and Courier (2 February 2017) $<$ https:// www.postandcourier.com/church_shooting/unsealed-documents-shed-lighton-dylann-roofs-mental-health-issues/article_404a01bc-e959-11e6-ad240f32fef $2 \mathrm{c} 5 \mathrm{bb} . \mathrm{html}>$

JAKE HALPERN, 'The Cop Darren Wilson was not indicted for shooting Michael Brown. Many People question whether Justice was done' The New Yorker (3 August 2015) $<$ https://www.newyorker.com/magazine/2015/08/10/the-cop>

JAMES RISEN, ET AL, 'U.S.-Approved Arms for Libya Rebels Fell into Jihadis' Hands' New York Times (5 December 2012) <https://www.nytimes.com/2012/12/06/ world/africa/weapons-sent-to-libyan-rebels-with-us-approval-fell-into-islamist -hands.html>

JANELLE GRIFFITH, 'Ahmaud Arbery Shooting: A Timeline of the Case' NBC News (12 May 2020) <https://www.nbcnews.com/news/us-news/ahmaud-arbery-shootingtimeline-case-n1204306>

JAY STANLEY, 'Police Body-Mounted Cameras: With Right Policies in Place, A Win For All' ACLU (March 2015) <https://www.aclu.org/other/police-body-mountedcameras-right-policies-place-win-all?redirect=police-body-mounted-camerasright-policies-place-win-all> 
JEFF PROCTOR, 'DA: Allegations of Police Tampering with Video warrant Federal Investigation' Criminal Justice \& Public Safety (21 November 2016) <https:// nmpoliticalreport.com/2016/11/21/da-allegations-of-police-tampering-withvideo-warrant-federal-investigation/>

JENNIFER WEBER \& WARREN HASSLER, 'The American Civil War' Encyclopedia Britannica $<$ https://www.britannica.com/event/American-Civil-War/The-war-in1862>

JEREMY ASHKENAS, ET AL, 'The Race Gap in America's Police Departments' New York Times (3 September 2014) < https://www.nytimes.com/interactive/2014/09/03/ us/the-race-gap-in-americas-police-departments.html?mtrref=www.google.com\& $\mathrm{gwh}=769 \mathrm{DCE} 1705226 \mathrm{C} 89783 \mathrm{CA} 65 \mathrm{~B} 7 \mathrm{FADE} 620 \& \mathrm{gwt}=$ pay \&assetType $=\mathrm{PAY}$ WALL>

MAEVE RESTON, 'Rodney King Shot While Riding Bike' Los Angeles Times (30 November 2007) <https://www.latimes.com/archives/la-xpm-2007-nov-30-meking30-story.html $>$

JOE FASSLER \& CLAIRE BROWN, 'Prison Food Is Making U.S. Inmates Disproportionately Sick' The Atlantic (27 December 2017) <https://www. theatlantic.com/health/archive/2017/12/prison-food-sickness-america/549179/>

JOSEPH GOLDSTEIN \& ASHLEY SOUTHALL, “' Got Tired of Hunting Black and Hispanic People' New York Times (9 December 2019) <https://www.nytimes. com/2019/12/06/nyregion/nyc-police-subway-racial-profiling.html>

JOSEPH GOLDSTEIN \& ASHLEY SOUTHALL, ' I Got Tired of Hunting Black and Hispanic People' New York Times (9 December 2019) <https://www.nytimes. com/2019/12/06/nyregion/nyc-police-subway-racial-profiling.html>

JOSEPH INIKORI, 'Slavery and the Revolution in Cotton Textile Production in England' (1989) 13(4) Social Science History, 343-379, 344.

JULIAN BORGER, 'New York on Edge as Police Kill Unarmed Man in Hail of 50 Bullets on His Wedding Day' The Guardian (7 November 2006) <https://www. theguardian.com/world/2006/nov/27/usa.julianborger>

JULIAN BURGER, 'New York on Edge as Police Kill Unarmed Man in Hail of 50 Bullets on His Wedding Day' The Guardian (7 November 2006) < https://www. theguardian.com/world/2006/nov/27/usa.julianborger>

JULIAN VELASCO, 'Shareholder Ownership and Primacy' (2010) University of Illinois Law Review 897, 944. <https://scholarship.law.nd.edu/law_faculty_ scholarship/319>

KAMAL GHALI, 'No Slavery Except as A Punishment for Crime: The Punishment Clause and Sexual Slavery' (2008) 55 UCLA Law Review 607, 608. <https:// www.uclalawreview.org/pdf/55-3-2.pdf> 
KATIE BENNER, 'Eric Garner's Death Will Not Lead to Federal Charges for NYPD Officer' New York Times (16 July 2019) < https://www.nytimes.com/2019/07/16/ nyregion/eric-garner-case-death-daniel-pantaleo.html>

KHALIL MUHAMMAD, 'The Sugar that saturates the American Diet has a Barbaric History as the 'white gold' that fueled Slavery' New York Times (14 August 2019) <https:// www.nytimes.com/interactive/2019/08/14/magazine/sugar-slave-trade-slavery.html>

KHRISTOPHER BROOKS, 'Disparity in Home Lending Costs Minorities Million, Researchers Find' CBS News (15 November 2019) <https://www.cbsnews. com/news/mortgage-discrimination-black-and-latino-paying-millions-more-ininterest-study-shows/>

LACY GRAY, 'Muslim Bashing in the Wake of Boston Bombing' National Geographic News (26 April 2013) <https://www.nationalgeographic.com/news/2013/4/130426-bostonmarathon-bombing-racism-hate-anti-arab-muslim-tamerlan-dzokhar-tsarnaev/>

LIBBY GEORGE, 'U.S., Jersey sign \$300 million Abacha Loot Reparation Deal with Nigeria' Reuters (4 February 2020) <https://www.reuters.com/article/us-usanigeria/u-s-jersey-sign-300-million-abacha-loot-repatriation-deal-with-nigeriaidUSKBN1ZY1W0>

LINDA MOORE, 'Tremaine Wilbourn Gets 38 Years Added to Life Sentence in Slaying of MPD Officer Sean Bolton' Commercial Appeal (17 December 2018) $<$ https:// www.commercialappeal.com/story/news/2018/12/17/memphis-police-killingtremaine-wilbourn-gets-38-years-added-life-sentence/2281111002/>

LOTTIE JOINER, 'How absent Fathers are hurting African American Boys' Center for Health Journalism, University of South Carolina <https://www. centerforhealthjournalism.org/resources/lessons/lessons-reporting-how-absentfathers-are-hurting-african-american-boys $>$

MADISON PARK, 'Police Shootings: Trials, Convictions are rare for Officers' CNN (3 October 2018) <https://edition.cnn.com/2017/05/18/us/police-involved-shootingcases/index.html>

MARTIN LUTHER KING JNR, 'I Have a Dream' The March on Washington (1963) $<$ https://www.archives.gov/files/press/exhibits/dream-speech.pdf $>$

ANTHONY CORDESMAN, 'The One True U.S. Strategic Interest in the Middle East: Energy' Middle East Policy Council (Spring 2001) <https://mepc.org/journal/onetrue-us-strategic-interest-middle-east-energy>

MARTIN LUTHER KING JNR, 'The Other America' Gross Pointe Historical America (14 March 1968) <https://www.gphistorical.org/mlk/mlkspeech/>

MATHEW SEAGAL, 'If Cops Don't Turn on Their Body Cameras, Courts Should Instruct Juries to Think Twice about Their Testimony' ACLU (1 December 2016) $<$ https://www.aclu.org/blog/criminal-law-reform/reforming-police/if-cops-dontturn-their-body-cameras-courts-should $>$ 
MEAGAN FLYNN 'US Officer pulled random People over and Planted Meth inside their Cars, causing them to lose their Freedom, their Children, their Marriages' Independent (12 July 2019) <https://www.independent.co.uk/news/world/ americas/police-us-planted-evidence-meth-marijuana-cars-florida-zacharya9001961.html>

MELLISA CHAN, 'A Police Officer Killed Their Mother, and Her Sons Want to Know Why He Hasn't Faced Trial' TIME (18 July 2019) < https://time.com/5628206/ police-shooting-trial-knowlton-garner/>

MERIT KENNEDY, 'Amid Breakdown in Nuclear Talks, North Korea Threatens U.S. With 'Christmas Gift” NPR (3 December 2019) <https://www.npr.org/2019/12/ 03/784380119/amid-breakdown-in-nuclear-talks-north-korea-threatens-u-s-with -christmas-gift>

MICHAEL FLETCHER, 'For Black Motorists, a Never-Ending Fear of Being Stopped' National Geographic Magazine/ the Race Issue <https://www.nationalgeographic. com/magazine/2018/04/the-stop-race-police-traffic/>

MICHAEL KLARE, 'Twenty-first Century Energy Wars: How Oil and Gas are fueling Global Conflicts' Energy Post (15 July 2014) <https://energypost.eu/twenty-firstcentury-energy-wars-oil-gas-fuelling-global-conflicts/>

MICHAEL WARREN, ET AL, 'Conservative Groups are Boosting the Anti-lockdown Protests - "I think the President wants this Country to get back to work' The Mercury News (21 April 2020) <https://www.mercurynews.com/2020/04/20/ conservative-groups-are-boosting-the-anti-lockdown-protests/>

MICHALE MARRIOT, 'Remembrance of Slave Ancestors Lost to the Sea' New York Times (19 June 1994) <https://www.nytimes.com/1994/06/19/nyregion/remembranceof-slave-ancestors-lost-to-the-sea.html>

MOHAMMED HADDAD, 'Mapping US Police Killings of Black Americans' Aljazeera (31 May 2020)<https://www.aljazeera.com/indepth/interactive/2020/05/mappingpolice-killings-black-americans-200531105741757.html>

NAJIM RAHIM \& ROD NORDLAND, 'AFamily of 14 Dies in an Airstrike. U.S. Officials Deny They Were Civilians' The New York Times (20 July 2018) <https://www. nytimes.com/2018/07/20/world/asia/afghanistan-us-civilian-casualties.html>

NEIL MUNSHI, 'Youth of Nigeria Force Buhari's Hand as Anger at Police Brutality Boils Over' Financial Times (15 October 2020) <https://www.ft.com/content/777c9f4ee071-49c8-98f6-abcd2e8b0d76>

NEWS CHANNEL 5, 'Suspect arrested for Lawrenceburg Double Murder' News Channel 5 (28 May 2020) <https://www.newschannel5.com/news/suspect-arrested-forlawrenceburg-double-murder $>$

NICOL LEE, 'Where would Racial Progress in Policing be without Camera Phones' Brookings (5 June 2020) < https://www.brookings.edu/blog/fixgov/2020/06/05/ where-would-racial-progress-in-policing-be-without-camera-phones/> 
NPR, 'A Decade of Watching Black People Die' Code Switch (31 May 2020) <https://www. npr.org/2020/05/29/865261916/a-decade-of-watching-black-people-die>

PETER WAGNER \& BERNADETTE RABUY, 'Following the Money of Mass Incarceration' Prison Policy Initiative (25 January 2017) <https://www. prisonpolicy.org/reports/money.html>

RACHEL SANDLER, 'George Floyd Had Coronavirus, Autopsy Finds, But it wasn't a Factor in His Death' Forbes (3 June 2020) <https://www.forbes.com/sites/ rachelsandler/2020/06/03/george-floyd-had-coronavirus-autopsy-finds-but-itwasnt-factor-in-his-death/\#3e87558c2b44>

RADLEY BALKO, 'It's Time to Abolish the Coroner' The Washington Post (12 December 2017) <https://www.washingtonpost.com/news/the-watch/wp/2017/12/12/itstime-to-abolish-the-coroner/>

ROB ARTHUR, ET AL, 'Shot by Cops and Forgotten' VICE News (11 December 2017) $<$ https://news.vice.com/en_us/article/xwvv3a/shot-by-cops $>$

ROB PICHETA \& HENRIK PETTERSON, 'American Police Shoot, Kill and Imprison more People than Other Developed Countries. Here's the Data' CNN (8 June 2020) < <ttps://edition.cnn.com/2020/06/08/us/us-police-floyd-protests-cou ntry-comparisons-intl/\#: :text=The $\% 20 \mathrm{US} \% 20$ has $\% 20$ the $\% 201$ argest,popula tions $\% 20$ around $\% 20$ the $\% 20$ world $\% 20$ annually.>

ROD NORDLAND, ET AL, 'How the U.S. Government Misleads the Public on Afghanistan' The New York Times (8 September 2018) <https://www.nytimes. com/interactive/2018/09/08/world/asia/us-misleads-on-afghanistan.html>

SAM LEVIN, 'Officer Punched Oscar Grant and Lied About Facts in 2009 Killing, Records Show' The Guardian (2 May 2019) < https://www.theguardian.com/usnews/2019/may/02/officer-punched-oscar-grant-and-lied-about-facts-in-2009killing-records-show $>$

SAMUEL GROSS, ET AL, 'Race and Wrongful Convictions in the United States' National Registry of Exonerations (7 March 2017) <http://www.law.umich.edu/ special/exoneration/Documents/Race_and_Wrongful_Convictions.pdf $>$

SAMUEL MORRISON, The Great Explorers: The European Discovery of America (Oxford University Press, 1986), pp. $351-365$.

SARAH MERVOSH, ‘Amber Guyger's Judge Gave Her a Bible and a Hug. Did That Cross a Line?' New York Times (4 October 2019) < https://www.nytimes.com/2019/10/04/ us/amber-guyger-judge-tammy-kemp-hug.html>

SCOTT SORIANO, 'Private Prisons are California Political Players' Capitol Weekly (7 September 2018) <https://capitolweekly.net/private-prisons-california-politicalplayers/>

SEAM ILLING, 'Why the Police Problem Isn't about a few Bad Apples' Vox (6 June 2020) <https://www.vox.com/identities/2020/6/2/21276799/george-floyd-protestcriminal-justice-paul-butler $>$ 
SEEMA SIROHI, 'US Protests: Why Black Activists Need Real Allies, Not 'Hijackers" The Quint (3 June 2020) <https:/www.thequint.com/voices/opinion/george-floydkilling-police-brutality-america-protests-black-lives-matter-vandalism-versuspeaceful-protest>

SHUAN KING, 'KING: How the 13th Amendment Didn't Really Abolish Slavery, but let it live on in U.S. Prisons' New York Daily News (21 September 2016) < https:// www.nydailynews.com/news/national/king-13th-amendment-didn-abolishslavery-article-1.2801218>

STANLEY ALPERN, 'What Africans Got for Their Slaves: A Master List of European Trade Goods' (1995) 22, History in Africa, 5-43, 6.

SUE DREMANN, 'Report: Police Tampered with Taser Recordings' Palo Alto Online (1 December 2008) <https://www.paloaltoonline.com/news/2008/12/01/reportpolice-tampered-with-taser-recordings $>$

SUE LANNIN, 'Afghanistan to begin first Commercial Oil Production' ABC News (18 May 2013) <https://www.abc.net.au/news/2013-05-18/australia-backs-afghan27 s-struggling-miners/4698082\#: :text=Afghanistan\%20has\%20untapped $\% 20$ mine ral $\% 20$ and,income $\% 20$ of $\% 20 \% 24470 \% 20$ per $\% 20$ year.>

SUSAN CRISS, 'Protecting Bad Police undermines Law and Order' The Daily News (7 June 2020) <https://www.galvnews.com/opinion/guest_columns/article f6f214de-b626-566e-bc52-284922d7461c.html>

TERINA ALLEN, '3 Things Amy Cooper Did in Central Park to Damage Her Reputation and Career' Forbes (29 May 2020) <https://www.forbes.com/sites/terinaa llen/2020/05/29/3-things-amy-cooper-did-in-central-park-that-destroyed-her-life /\#6abe2ba76198>

THE ENQUIRER, 'A Flag Photo of a Murder Suspect, a Mugshot of a Victim' Cincinnati. com (29 July 2015) <https://www.cincinnati.com/story/news/2015/07/29/samdubose-social-media-reaction-photo/30858745/>

THE LIBRARY OF CONGRESS, 'The Civil Rights Act of 1964: A Long Struggle for Freedom' The Segregation Era (1900-1939) <https://www.loc.gov/exhibits/civilrights-act/segregation-era.html>

TIM DECHRISTOPHER, 'The Value of Protest' Moyers on Democracy (23 July 2015) $<$ https://billmoyers.com/2015/07/23/the-value-of-protest/>

TIM REQUARTH, 'How Private Equity Is Turning Public Prisons Into Big Profits' The Nation (30 April 2019) < https://www.thenation.com/article/archive/prisonprivatization-private-equity-hig/>

TOM DART, 'Amber Guyger Guilty of Murdering Black Neighbor Botham Jean in His Own Home' The Guardian (1 October 2019) < https://www.theguardian.com/usnews/2019/oct/01/amber-guyger-texas-dallas-jury-botham-jean>

TRACY EVERBACH, ET AL, '\#IfTheyGunnedMeDown: An Analysis of Mainstream and Social Media in the Ferguson, Missouri, Shooting of Michael Brown' 
(2018) 12(1) Electronic News 23-41 <https://journals.sagepub.com/doi/pdf/10 $.1177 / 1931243117697767>$

UNITED STATES CENSUS BUREAU, 'Black or African American Population in the United States' (2019) <https://www.census.gov/quickfacts/fact/table/US/IPE1 20218>

UNITED STATES CENSUS BUREAU, 'The Population of White People in the United States' (2019) <https://www.census.gov/quickfacts/fact/table/US/IPE120218>

UNITED STATES FEDERAL REGISTER, 'Annual Determination of Average Cost of Incarceration' Prison Bureau (30 April 2018) <https://www.federalregister.gov/ documents/2018/04/30/2018-09062/annual-determination-of-average-cost-ofincarceration>

US HISTORY: Pre Columbian to the New Millennium, Slave Life and Slave Code $<$ https:// www.ushistory.org/us/27b.asp>

VAN NEWKIRK, 'The Great Land Robbery' The Atlantic (29 September 2019) <https:// Www.theatlantic.com/magazine/archive/2019/09/this-land-was-our-land/5 $94742 />$

VICTOR KAPPELER, 'A Brief History of Slavery and the Origins of American Policing' Eastern Kentucky University (7 January 2014) <https://plsonline.eku.edu/ insidelook/brief-history-slavery-and-origins-american-policing $>$

VICTORIA ALBERT, '911 Call from Breonna Taylor's Shooting Death Released: "Somebody Kicked in the Door and Shot My Girlfriend' CBS News (29 May 2020) <https://www.cbsnews.com/news/breonna-taylor-kenneth-walker-911-callpolice-shooting/>

WESLEY LOWERY, 'More Whites killed by Police, but Blacks 2.5 Times More Likely to be Killed' Chicago Tribune (11 July 2016) < https://www.chicagotribune.com/ nation-world/ct-police-shootings-race-20160711-story.html>

WHITNEY BENNS, 'American Slavery, Reinvented' The Atlantic (21 September 2015) <https://www.theatlantic.com/business/archive/2015/09/prison-labor-inamerica/406177/> 